\title{
The Buddhist Icon and the Modern Gaze
}

\section{Bernard Faure}

This essay is an attempt to reconsider what vision of-that is, what discourse on-Buddhist icons is possible for a Westerner (or Westernized Asian). Buddhist icons have been essentially the domain, or rather the preserve, of art historians. But Buddhist art, if there is such a thing, is perhaps too important to be left to art historians alone. Is there a Buddhist "art," a subcategory of Asian art, itself a rubric within world art, one among the many rooms in André Malraux's famous "musée imaginaire”? Or are we not dealing primarily with Buddhist images, whose artistic value is at best derivative? Even though art history is beginning to take a broader, even anthropological, perspective with regard to Western images and visual culture, it is still necessary in the Asian context to shift the focus from traditional concerns about the history and aesthetics of art to the history, affect, and function of ritual images or icons. Even if we want to retain the notion of aesthetic value, to the extent that a narrow aestheticism precludes our understanding of the anthropological and phenomenological dimensions of Buddhist icons, we must question this emphasis on the aesthetic object. I want to focus precisely on the vision of icons, on the asymmetrical exchange of glances that characterizes icon worship. I have elsewhere examined the various techniques of animation of the Buddhist icon. ${ }^{1}$ Because they are, in a manner, alive, and not sim-

I am greatly indebted to Mimi Yiengpruksawan, W. J. T. Mitchell, Irene Lin, and Aeron Hunt for their comments. Unless otherwise indicated, all translations are my own.

1. See Bernard Faure, The Rhetoric of Immediacy: A Cultural Critique of Chan/Zen Buddhism (Princeton, N.J., 1991), pp. 148-78 and Visions of Power: Imagining Medieval Japanese Bud- 
ply dead representations, these icons are images of power. However, this obvious point-perhaps because it is obvious in the etymological sense ("lying in the way"; hence preventing, making an obstacle)-has until recently been largely ignored by art historians, especially in studying Buddhist images. The notion of animated Buddhist icons has been repressed as a result of the modern and Western values of aestheticization, desacralization, and secularization. This situation, however, is beginning to change. ${ }^{2}$ In order to counteract this repression, I will take some of my cues from the recent work done by certain historians and from critiques of Western art in the wake of Walter Benjamin. ${ }^{3}$

I also want to question the scholar's instinctive reluctance to blur genres. What is at stake in this maintenance of the disciplinary border by the scholars who set themselves up as keepers of the pass, or of the passage? This question motivates my inquiry into the need and possibility

dhism, trans. Phyllis Brooks (Princeton, N.J., 1996), pp. 237-63. See also Michel Strickmann, Mantras et mandarins: Le Bouddhisme tantrique en Chine (Paris, 1996).

2. On Buddhist art, see the groundbreaking work of Paul Mus, Barabudur: Esquisse d'une histoire du bouddhisme fondée sur la critique archéologique des textes (1935; New York, 1978). See also G. Coedès, Pour mieux comprendre Angkor: Cultes personnels et culte royal; monuments funéraires; symbolisme architectural; les grands souverains d'Angkor (Paris, 1947); trans. and ed. Emily Floyd Gardiner, under the title Angkor: An Introduction (New York, 1963). See also Stanley K. Abe, "Inside the Wonder House: Buddhist Art and the West," in Curators of the Buddha: The Study of Buddhism under Colonialism, ed. Donald S. Lopez, Jr. (Chicago, 1995), pp. 63-106; hereafter abbreviated "IW." On East Asian art and ritual artifacts, see Doris Croissant, "Der unsterbliche Leib: Ahneneffigies und Reliquienporträt in der Porträtplastik Ostasiens," in Das Bildnis in der Kunst des Orients, ed. Martin Kraatz, Jürg Meyer zur Capellen, and Dietrich Seckel (Stuttgart, 1990), pp. 235-68; T. Griffith Foulk and Robert H. Sharf, "On the Ritual Use of Ch'an Portraiture in Medieval China," Cahiers d'Extrême-Asie 7 (199394): 149-219; and Mimi Yiengpruksawan, "In My Image: The Ichiji Kinrin Statue at Chūsonji," Monumenta Nipponica 46 (Autumn 1991): 329-47.

3. See, in particular, Walter Benjamin, "The Work of Art in the Age of Mechanical Reproduction," Illuminations, trans. Harry Zohn, ed. Hannah Arendt (New York, 1968), pp. 217-51, hereafter abbreviated "WA," and "On Some Motifs in Baudelaire," Illuminations, pp. 155-200; David Freedberg, The Power of Images: Studies in the History and Theory of Response (Chicago, 1989), hereafter abbreviated PI; W. J. T. Mitchell, Iconology: Image, Text, Ideology (Chicago, 1986); Visual Culture: Images and Interpretations, ed. Norman Bryson, Michael Ann Holly, and Keith Moxey (Hanover, N.H., 1994); Georges Didi-Huberman, Devant l'image: Question posée aux fins d'une histoire de l'art (Paris, 1990) and Ce que nous voyons, ce qui nous regarde (Paris, 1992).

Bernard Faure is professor of religious studies at Stanford University. He is the author of The Rhetoric of Immediacy: A Cultural Critique of Chan/Zen Buddhism (1991), Chan Insights and Oversights: An Epistemological Critique of the Chan Tradition (1993), Visions of Power: Imagining Medieval Japanese Buddhism (1996), and The Will to Orthodoxy: A Critical Genealogy of Northern Chan Buddhism (1997). 
for rethinking_or rather revising, reenvisioning-our understanding of the Buddhist icon, and by the same token perhaps modifying our gaze. The term icon, here, will designate mostly images such as statues and portraits (icons in the strict sense), but it could be extended to include aniconic, that is, nonanthropomorphic, symbols or diagrams (such as the Indian/Buddhist swastika or the wheel of the dharma). Icons, as we will see, are ritually animated and in this sense are not different from masks, puppets, or automatons, in which one finds the same "conflation of sign and signified" (PI, p. 32). At times, Buddhist icons are literally animated by the presence within them of a (supposedly) live entity. Paradoxically, then, the icon becomes a kind of tomb. A significant case is that of a Japanese stone statue of the Buddha Amida, in which was placed the mummy of a Buddhist monk. ${ }^{4}$ The icon becomes a container, a recipient, a funerary urn or stupa.

The labyrinthine structure of my argument might be partly justified when we recall that Daedalus, the first maker of animated images, was also the inventor of the labyrinth. Daedalus was the first to open the eyes of the statues, and to set their feet apart (see PI, pp. 36-37). Notice here the symbolic equivalence between eyes and legs: it is as if the opening of the eyes, which gives life, were equivalent to the separation of the legs, which permits movement. Buddhist icons, although their eyes have been opened, are usually represented sitting cross-legged or standing still with legs joined. Only a small number of Buddhist icons, representations of minor deities (what the Japanese call besson, "distinct worthies," as opposed to the major Buddhas, the honzon or "main worthies"), are depicted as dancing or gesturing wildly. On the whole, Buddhist iconology has valorized stillness. Buddhist icons are, strictly speaking, "still life" or "suspended animation." When they seem to be on the move, their movement often goes hand in hand with a certain sexualization. Whereas the honzon's immobility, its self-contained appearance, symbolizes its absence of passions (or outflows) and its genderlessness, the besson are more dynamic and clearly gendered (sometimes even quite explicitly, like images of the goddess Benzaiten, whose unclothed body is distinctly feminine).

\section{The Rise of Orientalist Aesthetics}

In what follows, I first examine the aesthetics of several early twentieth-century art historians, some of whom became at one point purveyors of Asian art to European and American audiences. I realize that

4. On Buddhist mummies, see Faure, The Rhetoric of Immediacy, pp. 148-78, and Sharf, "The Idolization of Enlightenment: On the Mummification of Ch'an Masters in Medieval China," History of Religions 32 (Aug. 1992): 1-31. 
modern art historians no longer find this aesthetic discourse valid, or worth discussing (if they ever did). No self-respecting specialist in Indian or Japanese art today finds his or her references in Ananda Coomaraswamy or Ernest Fenollosa. I still think it necessary, however, to emphasize what we might call the genealogical flaw of the Euro-American discourse on Asian art and its replication in the "secondary Orientalism" of native Asians, precisely because its Orientalist origins have receded into a dark corner and seem to have evaded scrutiny. ${ }^{5}$ A number of presuppositions that governed the discourse and vision of these predecessors are still influencing ours today. I would like to adumbrate some of these presuppositions by setting up a few straw men as (not so) ideal types.

The aesthetic tendency (and secondary Orientalism) in early Japanese art history is well represented by a historian like Watsuji Tetsurō, who in his book Restoring the Idols compared the Buddhist revival of the Taishō era (1912-25) to the Western Renaissance. The title of his book is, however, rather misleading, since the idols thus restored "did not revert to being gods to be worshipped but were now appreciated as works of art." 6 This return to antiquity was in fact, as in the French controversy between the Ancients and the Moderns, a departure from everything that had prevailed in the past; therefore, despite its title, the book advocated a radical modernism. The rediscovery of Buddhist doctrine and Buddhist art from the Taishō era onward followed in the wake of this modernist demythologization.

Another influential writer who was among those credited with (re)defining the fields of Japanese (or of Buddhist) art is Ernest Fenollosa. Hoping to serve as a bridge between the West and Japan, Fenollosa defined the parameters by which Chinese, Korean, and Japanese arts should be judged. In 1887 he received from the Japanese government the task of registering Japanese art treasures and through his lectures almost singlehandedly changed the Japanese people's perception of its cultural and artistic patrimony. Fenollosa was not only a fine lecturer at Tokyo Imperial University, he also became in 1890 the first curator of the Oriental collection (named after him) at the Boston Museum of Fine Arts. He went back to Japan in 1896 and, after his death in London in 1908, his ashes were buried at Miidera, the Buddhist monastery on the southern bank of Lake Biwa.

While in the United States, Fenollosa exerted a powerful influence

5. For a recent scrutiny of some of the Orientalist presuppositions of Buddhist art, see "IW." For a discussion of "secondary Orientalism," see Faure, Chan Insights and Oversights: An Epistemological Critique of the Chan Tradition (Princeton, N.J., 1993), pp. 52-88.

6. William R. LaFleur, "A Turning in Taishō: Asia and Europe in the Early Writings of Watsuji Tetsurō," in Culture and Identity: Japanese Intellectuals during the Interwar Years, ed. J. Thomas Rimer (Princeton, N.J., 1990), p. 239. 
on American art education, namely with his emphasis on the notion of "spacing" and his assertion that "style" was a "shibboleth," reflected in statements like the following: "We find that all art is harmonious spacing, under special technical conditions that vary." By attempting to give "a history of Oriental Art written from a universal point of view," he contributed more than any other Westerner to the enshrinement of Buddhist imagery into so-called universal art $(E C, 1: \mathrm{xxv})$. In the introduction to his Epochs of Chinese and Japanese Art, he wrote, for instance: "We are approaching the time when the art work of all the world of man may be looked upon as one, as infinite variations in a single kind of mental and social effort" (EC, 1:xxiv).

The crucial role played by Fenollosa in rescuing Japanese Buddhist art and, as his wife, Mary, claims in her preface to his work, restoring Japanese "national pride and interest" cannot be denied (EC, 1:xvi). However, this achievement was not without cost, in artistic as well as ideological terms. In light of our knowledge of what this restored national pride led to, the preface's claim that Fenollosa was "deeply stirred by the splendid struggle of Japan in her war with Russia" is disturbing ( $E C$, 1:xxi). Conflating religion and ideology, he was led to believe that the "passionate idealism" of "this remarkable race" had "displayed itself in the sacrifices of the recent Russian war" (EC, 1:155). From an art historical point of view, the cost has to do with the aestheticization of Buddhist images-the purely stylistic approach to the "epochs of art"-with hardly a word as to the functions of and responses to this art. Fenollosa's idealization of Asian images as sublime works of art, comparable and even superior in some respects to Greek art, goes hand in hand with a lack of interest in their cultic functions. A significant example is his account of the discovery in 1884 of the Yumedono Kannon of Höryüji, an icon which had been kept hidden in its "Pavilion of Dreams" (yumedono) for centuries. But, says Fenollosa, "it was the aesthetic wonders of this work that attracted us most," a work that "seemed to rise to the height of archaic Greek art," with "its rather large-almost negroid-lips, on which a quiet mysterious smile played, not unlike Da Vinci's Mona Lisa's" and a slimness "like a Gothic statue from Amiens" $(E C, 1: 51){ }^{8}$ Here is Malraux's "musée imaginaire" in a nutshell: "As one stands upon the altar of Kondo,

7. Ernest F. Fenollosa, Epochs of Chinese and Japanese Art: An Outline History of East Asiatic Design, 2 vols. (New York, 1913), 1:xxiv; hereafter abbreviated $E C$.

8. Not surprisingly, the classical reference is omnipresent in Western judgments about Asian art. When Aurel Stein begins to explore Buddhist sites in the Swat district of Northern India with Alfred Foucher in 1896, he writes: "I feel I am on classical soil and enjoyed every minute" (quoted in "IW," p. 85). As Abe points out, "'Greekness' . . serves to designate the aesthetic superiority of the European colonial" ("IW," p. 71). This bias toward antiquity is still visible in the titles of major journals in the field: Artibus Asiae, Ars Orientalisto name just a few. But in the case of Gandhara art, unlike in the present case, the thickness of the lips of some statues was judged as a proof of non-Greek origin; see ibid., p. 71. 
he gets to-day a strange, weird feeling of Greekish frescoes, Norman hangings, Gothic statues, and Egyptian bronzes, so varied is the jumble of forms of a hundred sizes" (EC, 1:59).

In all fairness, Fenollosa does at times, though rarely, depart from his purely aesthetic mode and reflect on the response that these icons could provoke from the (Christian) beholder. Thus, speaking of the Maitreya of Hōryūji, he writes: "The impression of this figure, as one views it for the first time, is of intense holiness. No serious, broad-minded Christian could quite free himself from the impulse to bow down before its sweet powerful smile. With all its primitive coarseness of detail, ... it dominates the whole room like an actual presence" $(E C, 1: 64)$. But on the whole, he remains mainly interested in the line, color, and grace of Buddhist art, this "aesthetic flowering of the Japanese race" $(E C, 1: 99)$. When one of these standards is not met, he is quick to denounce the ugliness of what he observes, as in the case of Nara's Great Buddha, with its "ugly big head," reflecting "the taste of the day ... for fat and neckless types" $(E C, 1: 109)$. The same is true for the Eighteen Arhats of Kodaiji, which, with their "evidently intentional" Semitic features, lacking any grace, he argues must have been found in Chinese synagogues, for "the Arabs hated Buddhism so heartily that they would hardly have become mistaken for [arhats]" (EC, 1:142). Fenollosa does not even mention the obvious ideological and cultic aspects of these icons, in particular the Vairocana Buddha of Todaiji, whose ritual "eye-opening" ceremony in 753 crowned a massive effort to gather the metal for the statue that strained the state's resources.

Fenollosa's interest in line (perhaps showing the distant influence of Vasari) and color leads him to assert the superiority of painting over sculpture: "The very rhythms of line may suggest motion and transitory phases which are forbidden to sculpture. The latter normally registers the permanent; the former the process" (EC, 1:122). Sculpture seems to be the first stage in artistic evolution, correlated with public religious worship; but with the growth of individual religiosity, painting comes to the foreground, as for instance is the case with the "mystical," antiritualistic art of Chan/Zen. We are now "to follow Chinese and Japanese art into the greater subtleties of painting, the ripe stage of infinite modulations in line and colour" $(E C, 1: 123)$. Because painting constitutes the ultimate reference, Buddhist sculpture is judged on the basis of its lines, the grace of its forms. When the line fails, it may be partly redeemed by the richness of the color, but in most cases ugliness ensues.

For Fenollosa, therefore, as for historians of Western art like Heinrich Wölfflin, the history of art is one of the development of forms. ${ }^{9}$ This

9. See Heinrich Wölfflin, Principles of Art History: The Problem of the Development of Style in Later Art, trans. M. D. Hottinger (New York, 1950). 
emphasis on the stylistic form prevented him, and many after him, from reflecting on the ritual context of the icons he discovered. Aesthetic considerations have steered us away, for instance, from exploring all the implications of the well-known (and often mentioned) fact that the Guze Kannon icon and the Sāayamuni icon at Hōryūji were made the size of the ruler Shōtoku Taishi (572-621). The size of an icon was one of the essential elements in the success of a ritual. As Sylvain Lévi pointed out in his analysis of Vedic sacrifice, "the sacrifice is the man. The sacrifice is the man because it is man who offers it; and every time it is offered, the sacrifice has the size of the man." 10 The Guze Kannon is even believed to be an image of Shötoku Taishi, made while he was alive. In other words, whereas these icons were substitute bodies, tokens of immortality, many of us, a century after Fenollosa, still see them as items in the catalogue of the "musée imaginaire," next to the Venus de Milo, the Mona Lisa, and Rodin's The Thinker. To give just one example, quoted with approbation by a contemporary art historian, Karl Jaspers saw the famous Maitreya icon of Köryūji as a "symbol of the purest, the most harmonious and the most eternal [sic] of the human 'being,' freed from the hindrances of the temporal that rules over this earth." ${ }^{11}$ No doubt Jaspers would have been surprised to hear that-unlike in the case of the Venus de Milo, whose beauty is enhanced by her incompleteness-when a finger of this Maitreya was broken by a high-school student in 1960, the whole country followed the media's hour-by-hour account of the recovery of the wounded icon. All this does not detract from Fenollosa's achievementsor does it? At the very least, one could say of him what he says of one of his predecessors: "Marco Polo is surely worth something" (EC, 1:xxix) ${ }^{12}$

10. "Le sacrifice, c'est l'homme. Le sacrifice est l'homme car c'est l'homme qui l'offre; et chaque fois qu'il est offert, le sacrifice a la taille de l'homme" (Catapatha-Brāhmana, quoted in Sylvain Lévi, La Doctrine du sacrifice dans les Brahmanas [1898; Paris, 1966], p. 77).

11. Quoted in François Berthier, Genèse de la sculpture bouddhique japonaise (Paris, 1979), p. 313. The formalist approach of Japanese art historians to Buddhist sculpture is well documented (and replicated) in Berthier's book.

12. Another representative instance of the aestheticizing tendency is Hisamatsu Shin'ichi's construction of a Zen aesthetics under a definition so broad that it allowed him, like Fenollosa's friend Okakura Kakuzō and Suzuki Daisetsu, the scholar and lay Zen practitioner who popularized Zen in the United States, to include under the banner of Zen a broad variety of cultural products such as the tea ceremony, flower arrangement, nō theater, and haiku poetry. I have discussed this aspect of Zen ideology elsewhere. See Faure, Chan Insights and Oversights, pp. 52-88. Hisamatsu defines Zen aesthetics under seven rubrics: asymmetry, simplicity, timelessness, naturalness, subtle profundity (yügen), freedom from convention or attachment, and aloneness. See Gregory Noyes, "The Rainbow of Zen Aesthetics" (Ph.D. diss., Stanford University, 1993). For a direct contact with Zen ideology, see Hisamatsu Shin'ichi, Zen and the Fine Arts, trans. Tokiwa Gishin (Tokyo, 1971); Okakura Kakuzō, The Ideals of the East, with Special Reference to the Art of Japan (London, 1903); and Daisetz T. Suzuki, Zen and Japanese Culture, 2d ed. (Princeton, N.J., 1970). 


\section{The Sacralization of Art and the Profanation of Icons}

In the case of the Yumedono Kannon as in many others, Fenollosa, acting on behalf of the Meiji government, was able to requisition the opening of the pavilion, despite the protestations of the resident monks: "They resisted long, alleging that in punishment for the sacrilege an earthquake might well destroy the temple. Finally we prevailed, and I shall never forget our feelings as the long disused key rattled in the rusty lock. Within the shrine appeared a tall mass closely wrapped about in swathing bands of cotton cloth, upon which the dust of ages had gathered." The atmosphere of profanation that prevails here recalls the Western discovery of Egyptian mummies, but this violence in the name of art is well worth it in Fenollosa's text, since "at last the final folds of the covering fell away, and this marvellous statue, unique in the world, came forth to human sight for the first time in centuries" $(E C, 1: 50)$.

The earlier mention of Malraux in relation to the notion of universal art, of the "musée imaginaire" (an expression that E. H. Gombrich translates as "Museum of the mind"), is significant in other respects as well. ${ }^{13}$ One of the lesser claims to fame of this colorful figure, who became the first minister of culture of the Fifth Republic, is the story of his arrest in his youth for stealing the head of a Buddhist statue from Angkor. Art and violence form an old couple, and Buddhist temples, from India to Japan, were plundered long before Malraux. When Indiana Jones tries to retrieve a precious cross from the hands of avid collectors, angrily protesting, "It belongs in a museum!" he is more akin to the thieves than he might think. ${ }^{14}$ However, this plundering was usually committed for venal reasons, rarely in the name of aesthetics (and even when it was, as in Malraux's case, aesthetics seems more like an alibi or an afterthoughtor perhaps a mark of remorse). This enshrining of aesthetic pieces (and fragments) in the temple of art by profaning the icons of the temple (literally, bringing them from inside the temple to outside, in broad daylight, in front of the temple [pro fanum]) brings to mind an even more dramatic case, that of Victor Segalen, a noted French poet and novelist, who also became well known in the sinological field for his research on Chinese archeology. In his epigraph to Segalen's book, The Great Statuary of China, Malraux writes: "The great poet who wrote Stèles here reveals to us, as no one had ever done before and as no one since has done, the spirit of the art he studied. In its field, this book is irreplaceable." ${ }^{15}$ One wonders whether Malraux knew about the following incident, narrated by Sega-

13. E. H. Gombrich, "Malraux's Philosophy of Art in Historical Perspective," in André Malraux, ed. Harold Bloom (New York, 1988), p. 137.

14. Indiana Jones and the Last Crusade, prod. George Lucas and Frank Marshall, dir. Steven Spielberg, 1989.

15. Andre Malraux, epigraph to Victor Segalen, The Great Statuary of China, trans. Eleanor Levieux, ed. A. Joly-Segalen (Chicago, 1978); hereafter abbreviated GS. 
len's companion, Gilbert de Voisins. If he had, would it have changed his appreciation of Segalen as a great poet uniquely able to reveal to us the spirit of Chinese art? Or would the revelation of this dirty secret have, on the contrary, illuminated in his eyes the essence of connoisseurship?

On 29 August 1909, upon stopping to visit a dilapidated pagoda on the roadside, Segalen and de Voisins discover a splendid statue of Buddha:

Despite its missing two arms and a torso that seemed to be in poor shape, this life-size statue is still alive: its profile has retained its nobility, its eyes their gaze, the smile of its mouth its generous sweetness and a kind of irony.-This statue, we must have it! We won't leave it as if it were a mere bronze vase! We will not leave without it! With chosen words that bind us, we make a pledge.-This is all very well, but how should we proceed? Take it? Steal it?-It would be impossible for us even to lift that piece of wood! Very well then! We will cut its head! Immediately, fetching an axe from our luggage, we undertake the sacrilegious work. With all my strength, I strike the first blow on the golden neck, but I hardly make a mark on this age-old wood. We struggle in vain. Segalen strikes with all his strength, without any more success. This lasts for about half an hour, when just as we are about to give up ... two peasants who were passing on the road, attracted by the noise, enter suddenly. We feel quite embarrassed, our cynicism has its limits. . . . To pollute a temple by debasing the statue of its god is an act for which there is hardly any excuse. But the newcomers, far from showing any anger or indignation, behave, on the contrary, in a way that stupefies us: they offer to help us!-First, they make us understand that it is pointless to try to behead this Buddha, which is too heavy, while standing. They lay it down on its face, with its head on a block, put wedges under its sides, fix it with straw plugs, and finally, laughing at our clumsiness, take the axe from our hands. With a few well-directed strokes, crackles, an atrocious tear, it is done; the beheading is perpetrated. In the chest we find some cash, which we leave to our accomplices, and papers, which I keep. Our horses are now stamping in the mud. We jump into the saddle without further delay and ride away. ... On the way back, Segalen imagines the plot of a nice story, based on our action today. He is so ashamed of this sacrilege that he wants to justify himself to posterity. In particular, he is so ashamed of our impunity that he heaps a thousand calamities, each more atrocious than the other, on the main character of his story. In this way, he believes that he can to some extent avoid them himself. Only when he laid out the conclusion of his story, which I may add is perfectly horrible, did he perhaps feel relieved and find his peace of mind again. ${ }^{16}$

16. Augusto Gilbert de Voisins, Écrit en Chine, in Le Voyage en Chine: Anthologie des voyageurs occidentaux du Moyen Âge à la chute de l'Empire chinois, ed. Ninette Boothroyd, Muriel Détrie, and Fernand Bunel (Paris, 1992), pp. 1053-54. 
Interestingly, Segalen exorcizes or placates one double (the icon) by punishing another (the character in his story).

Would Segalen have committed the same profanation if the icon had not been a Buddhist one? Sometimes the idealization of one type of art is achieved at the cost of another. Segalen calls Buddhist sculptures "outgrowths of apostolic Hinduism" and refuses to consider them as examples of "China's true statues" (GS, p. 15). These sculptures, being the "repetition of one monotonous type," are "of the same stiff ecstasy" and are "neither beautiful nor Chinese" (GS, p. 121). Segalen deplores the tragedy that famous sites such as Yungang and Longmen are "no longer anything but an empty sponge, a once-living core putrefied by the hand of man" (GS, p. 122). He does not try to hide his prejudice against Buddhism, "what we must call and consider China's major heresy, her fault, her slavery" (GS, p. 79). If he feels obliged to talk about Buddhist art at all, it is "in order to challenge and reject the lyrical admiration with which that 'art' had been treated" - an art "so remote, so exotic, so waning" compared to the "pure, intrinsic, inherently Chinese nature of the genius of ancient China expressed in three-dimensional stone" (GS, pp. 128, 119). ${ }^{17}$ Yet the Buddhist statue was beautiful enough, with the "generous sweetness" and the "kind of irony" of its smile, for Segalen to desire its possession at any cost.

The point is not to lay blame on some individuals in order to exonerate ourseives more easily but rather to register the intrinsic violence of the modern gaze and discourse, the predatory nature of our relation with non-Western cultures-a violence so deeply embedded that it infected even the best minds, but a desecration that is also perhaps incited by the sacred icon itself. ${ }^{18}$ The commodity fetishism that characterizes much of the discourse about art today may be simply another expression of the intrinsic violence done to the image, although it can also be analyzed as part of the lingering fascination exerted by it, and as a way of recharging things with alienated "powers." Or again, as Freedberg argues, the violence might be done not only to the object but to oneself. The aesthetic mode of thought might be the active repression of an animistic belief in the power of images, the very kind of repression of outdated feelings that

17. See also Yvonne Y. Hsieh, Victor Segalen's Literary Encounter with China: Chinese Moulds, Western Thoughts (Toronto, 1988), pp. 31, 107-8.

18. Another case in point is that of Michel Leiris, a surrealist writer who became an ethnographer when he joined the mission organized by Marcel Griaule in Africa to collect specimens of African art and culture for the Musée de l'Homme. Leiris denounces colonial violence, but he also recounts in his diary, later published despite Griaule's opposition under the title L'Afrique fantôme, how he stole precious fetishes from unsuspecting villagers. On Griaule, Leiris, and Segalen, see James Clifford, The Predicament of Culture: Twentieth-Century Ethnography, Literature, and Art (Cambridge, Mass., 1988), pp. 55-90, 152-74. 
Freud sees as the source of the uncanny. As the above example suggests, there is sometimes a fine line between iconophilia and iconoclasm. ${ }^{19}$

\section{The Desire for Vision}

If unlike the devotional or ritualistic approach-and more than the traditional Buddhist emphasis on beauty-the modern aesthetic approach is essentially a strategy for containing the "impure" (sexual or magical) elements of cultural artifacts, we need to move beyond aesthetic discourse to consider the abundant, yet neglected, anthropological data regarding (and regarded by) the icon. Among these we might want to include Indian and Chinese notions about the gaze (in Sanskrit, darśan), the stupa (a reliquary mound housing the relics of the Buddha or of a saint), the tessera (in Chinese, $f u$ ), and power (in Chinese, ling).$^{20} \mathrm{~A}$ case for the importance of context has been made by Edmund Leach, who argues that icons are part of a "space syntax" of sacred buildings (and, we could add, of domestic worship) and that one cannot remove them from this context without entirely changing their nature. ${ }^{21}$ For Leach, "works of art are not just things in themselves, they are objects carrying moral implications. What the moral implication is depends upon where they are" ("GH," p. 256). What we call the loss of aura results in this case from the displacement of the icon from its religious context and not merely, as Walter Benjamin argued, from mechanical reproduction. Although some icons are displaced a great deal in traditional cultures and actually derive much of their power from this, their displacement does not entail a dislocation of their meaning. One could perhaps distinguish between the

19. A similar point is made, in a different context, by Mitchell in his discussion of the modern "rhetoric of iconoclasm." See Mitchell, Iconology, pp. 160-208. On the Buddhist "rhetoric of iconoclasm," see Richard Gombrich, "The Consecration of a Buddhist Image," Journal of Asian Studies 26 (Nov. 1966): 23-36.

20. On the animate icon, see Richard Gombrich, "The Consecration of a Buddhist Image," and Strickmann, Mantras et mandarins. On the Indian "gaze" (darśan), see J. Gonda, Eye and Gaze in the Veda (Amsterdam, 1969); on the tessera, see Max Kaltenmark, "Ling-pao: Note sur un terme du taoïsme religieux," in Mélanges publiés par l'Institut des Hautes Études Chinoises, 2 vols. (Paris, 1960), 1:559-88; on the stupa, see Mus's monumental work, Barabudur; on power, see Marcel Mauss and Henri Hubert, $A$ General Theory of Magic, trans. Robert Brain (New York, 1972); Stanley Jeyaraja Tambiah, The Buddhist Saints of the Forest and the Cult of Amulets: A Study in Charisma, Hagiography, Sectarianism, and Millenial Buddhism (Cambridge, 1984); and $P I$.

21. Edmund R. Leach, "The Gatekeepers of Heaven: Anthropological Aspects of Grandiose Architecture," Journal of Anthropological Research 39 (Fall 1983): 244; hereafter abbreviated "GH." The worst-case scenario, only too common, is that of these icons who, like the Buddha from Hoti Mardan described by Foucher, came to decorate the mess hall of a British frontier garrison, "leaning against the wall of the dining-room and no longer inhaling any incense but the smoke of cigars" (quoted in "IW," pp. 85-86). 
syntactic level, on which an icon appears as part of an iconological structure or network (a triad, and so forth), and the semantic level, which abstracts that icon from its synchronic or metonymic associations not in order to re-create another sequence, a diachronic one, but rather to focus on its individual aura, its unique presence. Leach focusses on group representations, in which "the jumble is the message" ("GH," p. 250). A case in point, which both he and Rolf Stein study, is the representation of the Gatekeepers-who usually form a "dual" of persons, a pair of twins that should not be separated. ${ }^{22}$ In the twin pagodas of Zayton (Quanzhou), studied by Gustav Ecke and Paul Demiéville, icons are structurally paired..$^{23}$ These pagodas, whose photographic study necessitated the construction of a complex scaffolding, reveal another interesting fact: in many cases icons are not there to be seen, either because they are placed too high or because they are buried (literally encrypted) or kept hidden (the so-called hibutsu, or "hidden Buddhas"). ${ }^{24} \mathrm{~A}$ dominant metaphor in art nowadays, which explains the art critic's interest in a hermeneutic or semiotic approach and Leach's structuralism, is that of the text to be deciphered (dé-crypté). However, images are not simply there to be seen or read. Even in the case of icons carved on a stupa, "circumambulation does not lend itself to aesthetic contemplation." ${ }^{25}$

Despite its highly abstract metaphysics, Buddhism, through its iconic and ritualistic tendency, remains an eminently concrete religion. As noted above, the cult of icons is characterized by strategies of presence. The notion of presence might seem too reminiscent of Christianity, but in this respect Christian iconology itself, unlike Jewish iconoclasm, savored of paganism. Christianity (or Western philosophy, according to Derrida) does not have the privilege of a "metaphysics of presence." ${ }^{6}$ Such a metaphysics is one of the most commonly used strategies and one of the most common features of religious ideologies across cultures.

The figurative practice in China has its antecedents in magical conceptions related to witchcraft, funerary, and ritual practices, in contrast

22. See "GH," and Rolf A. Stein, "The Guardian of the Gate: An Example of Buddhist Mythology, from India to Japan," in Asian Mythologies, trans. Wendy Doniger et al., ed. Yves Bonnefoy (Chicago, 1991), pp. 122-36. As Roland Barthes pointed out, the French word duel has both the meanings of "duel," or contest, and "dual," the category in Greek grammar between singular and plural. See Roland Barthes, "Introduction to the Structural Analysis of Narratives," Image-Music-Text, trans. and ed. Stephen Heath (New York, 1977), p. 108.

23. See G. Ecke and P. Demiéville, The Twin Pagodas of Zayton: A Study of Later Buddhist Sculpture in China (Cambridge, Mass., 1935).

24. The same is true of Buddhist relics and regalia. See, for instance, Faure, "Relics, Regalia, and the Ideology of Secrecy," in Rending the Veil, ed. Eliott Wolfson (forthcoming).

25. Stella Kramrisch, Exploring India's Sacred Art: Selected Writings of Stella Kramrisch, ed. Barbara Stoler Miller (Philadelphia, 1983), p. 217; hereafter abbreviated EI.

26. On the metaphysics of presence, see Jacques Derrida, Of Grammatology, trans. Gayatri Chakravorty Spivak (Baltimore, 1974). 
to the figurative practice of the West, where a clear break seems to have occurred. ${ }^{27}$ The Western image is, in the words of Jean-Pierre Vernant, "only resemblance," and "this pure similitude that defines its nature of image marks it with the seal of a total irreality." ${ }^{28}$ However, the contrast is perhaps not as clear-cut as Hubert Delahaye, for one, thinks. Delahaye nevertheless makes the interesting point that statues in China do not reflect a divine reality; they are not mere illusions or repositories of a higher power, but refer only to themselves-a signifier without signified, as it were. As we will see, this is not always the case for Chinese sculpture, or at least for Buddhist icons.

In some cases, Buddhist icons were so true to life as to be endowed with viscera, the most famous example being that of Seiryōji in Kyoto, a wooden Buddha dated 985, in which five cloth entrails were found along with a variety of votive objects and relics. Likewise the statue of the Buddhist master Zendō (Shandao) at Chion-in contains a number of objects (a mirror, coins, written prayers, and so forth). Some of these "stuffed" Buddhas are verisimilar to the point of having inlaid glass eyes. The blood, sweat, and tears of sculptures were usually seen as bad omens. Sometimes icons grow hair or eyebrows, another ominous sign, or cry for help when robbers come to steal them. Sometimes the icon can be a stupa, as in the following story: Having noticed an old woman climbing a mountain every day to worship a stupa, some youths ask her why she takes such pains. She answers that it is because of a prophecy that the apparition of blood on this stupa would mean an imminent disaster. The youths decide to smear the stupa with blood to laugh at the old woman's expense. The next day, when she sees the blood on the stupa, she runs down the mountain and leaves the village. Soon after, a sudden flood devastates the valley, fulfilling the prophecy. ${ }^{29}$ I will return to the equivalence between stupa and icon below.

There are many cases like the following, in which Asian icons, because of their verisimilitude, their mimetic quality, are able to arouse people. Here are a couple of Chinese examples:

During the Xianning era of the Song, three young men went to a sanctuary on Mount Jiang. There were several statues of very beautiful and worthy women. The young men got drunk, and everyone chose a statue as a spouse and began to flirt with her. They [played] thus until the evening; during the night, they all had the same dream, in which the lord of Mount Jiang sent a messenger who trans-

27. See Hubert Delahaye, "Les Antécédents magiques des statues chinoises," Revue d'esthétique, n.s., 5 (1983): 45-53; hereafter abbreviated "AM."

28. Jean-Pierre Vernant, "Étude comparée des religions antiques," Annuaire du Collège de France 77 (1977): 426.

29. See Konjaku monogatari shū, trans. and ed. Bernard Frank, under the title Histoires qui sont maintenant du passé (Paris, 1968), pp. 94-96. 
mitted this message: "My daughters are all old and ugly, and yet we have received the favor of your homages and solicitude. We must therefore fix the day and month when you will all meet again for the wedding." 30

Soon after, all the young men died. Another story is found in Hong Mai's Yijian zhi (Record of the Listener), from the second half of the twelfth century:

There was in Chaojue monastery ... a hall of the Mother with Nine Children. It was on the top of the mountain. A lay practitioner named Huang went to offer incense and lamps, and, among the statues, he took [particular] care of a statue of a wet nurse. Her breasts hung outside her robe, offering a pleasant sight. Every time he came, he caressed her breasts with sighs of pleasure. One morning, the statue moved her eyes and got up. She took him by the hand, led him behind a screen, and they had intercourse. From that day onward, they maintained the habit. After several months, the man fell ill and had to stay in bed. However, he continued to climb the mountain. The abbot of the monastery spied on him, and saw a woman welcoming him with laughter halfway to the top. The next day the abbot followed him: the woman was there again. The abbot hit her with a staff, and she collapsed on the ground. In the terracotta fragments [of the statue] he found a fetus which seemed to have been gestating for several months. He ordered Huang to take it home; then suddenly the fetus broke in a thousand pieces. [Huang] mixed [bits of] the fetus into a drug which he then swallowed, and subsequently recovered. ${ }^{31}$

We find here a very concrete description of fetishism as the animation of an object through the projection of one's own life. If unchecked, such alienation leads to the death of the fetishist, through the birth of his double. ${ }^{32}$

In Japan, the best-known story is that of Kichijoten (in Sanskrit, Lakṣmī) in the Nihon ryoitki (Record of Miraculous Stories from Japan): In a mountain temple of Chinu there was a clay image of the goddess Kichijō. A lay brother who lived in the temple was attracted to the female image, felt desire, and fell in love with it. This Buddhist Pygmalion prayed to the goddess six times a day, asking her to give him a beautiful woman like herself. Subsequently he dreamed that he had sexual intercourse with the goddess; the next morning he discovered a stain on the skirt of her image. Seeing this, he repented, saying, "II prayed to you to

30. Lu Xun, Gu xiaoshuo gouchen (Hong Kong, 1970), p. 428; quoted in "AM," p. 48.

31. Hong Mai, Yijian zhi, ed. Congshu Jicheng (Beijing, 1981), p. 129; quoted in "AM," p. 51. 185-96.

32. For a discussion of the Marxist notion of fetishism, see Mitchell, Iconology, pp. 
give me a woman like yourself, but what a sacrifice you made to give yourself to me." He was too ashamed to tell others, but the whole affair was eventually discovered, and villagers found the stain on the statue. The text concludes by saying that "deep faith never fails to gain response." 33

Delahaye contrasts the world of Chinese painters, who were usually literati and therefore opposed to magical aspects of their art, to that of sculptors and craftsmen, who remained closer to the cultic context of popular culture. In both cases, however, image makers were seen as demiurges, able, like Pygmalion, to breathe life into their creations. Even the most abstract concepts of Chinese aesthetics betray their magic origins. As noted above, the lifelike nature of the icon manifests itself in its movement: icons can speak, walk, fly. Sometimes the icon walks around its own pedestal, from which it has climbed down. The first Buddhist image was also the first icon that moved. Here is how the Gaoseng zhuan (Biographies of Eminent Monks) tells the story of the origin of this icon:

The Buddha had gone ninety days earlier to the Trāyastrimśa Heaven to preach the Law to his mother. King Prasenajit [or, in a variant, King Udayana], regretting not being able to see him, had a statue carved in sandalwood ... and had it placed at the spot where the Buddha used to sit. Later, when the Buddha returned to his vihara, the statue came out to welcome him. The Buddha said: "Return to your seat. After my nirvana, you will serve as model to the four categories of followers." The statue sat down. This statue is the first of a multitude. ${ }^{34}$

A replica of this icon (or, in some versions, the original-which was, of course, already in a sense a replica) was allegedly brought to Japan by the priest Chonen at the end of the eleventh century and enshrined at Seiryōji (Shakadō) in Kyoto. This icon is the one in which cloth viscera were found, a fact that in part explains its vitality. However, in China, the notion of live icons predates Buddhism, and animated effigies were already found in the tombs of the Han. Of course, this widespread cultural notion ran against the intellectualist approach of doctrinal Buddhism. In the early canonical scriptures, one often reads that the Buddha is not in his image. In the Daoxing jing, for instance, the Bodhisattva Dharmodgata

33. "On Lustful Love for the Image of Kichijō-tennyo, Which Responded with an Extraordinary Sign," Miraculous Stories from the Japanese Buddhist Tradition: The "Nihon Ryöiki" of the Monk Kyōkai, trans. Kyoko Motomochi Nakamura (Cambridge, Mass., 1973), p. 178.

34. Gaoseng zhuan, in Taishō shinshü daizōkyō, ed. Takakusu Junjirō and Watanabe Kaigyoku, 100 vols. (Tokyo, 1924-32), 50:860b. On the legend of the Buddha image, see Hōbōgirin: Dictionnaire encyclopédique du bouddhisme d'après les sources chinoises et japonaises, ed. Demiéville, Lévi, and J. Takakusu, s.v. "Butsuzō," and Donald F. McCallum, The Zenkōji Icon: A Study in Medieval Japanese Religious Art (Princeton, N.J., 1994). 
asks his disciple, Sadāprarudita, "O Noble One, would you say that the Buddha's spirit is in the image?" Sadāprarudita replies, "It is not there. The image of the Buddha is made (only) because one desires to have men acquire merit." 35

Similarly, the well-known story in which Upagupta asks the Tempter Māra to impersonate the Buddha Sākyamuni is an early attempt to distinguish Buddhist icon worship from "pagan" fetishism: When the patriarch Upagupta wants to see the Buddha, the demon Māra impersonates him, to Upagupta's delight. However, Upagupta makes it clear that his devotion goes to the Buddha, not to Marra. ${ }^{36}$ We are reminded of the Byzantine iconodules' statement that the devotion goes to the prototype and that the image and the prototype are not to be confused..$^{37}$

These stories suggest that in most cases the icon finds its origin in a desire for vision and/or presence. The same desire is found at the source of Christian icons. Like King Prasenajit (or Udayana) requesting the right to make an image of the Buddha Śākyamuni, Saint Veronica, in one version of her legend, asks for an image of the Christ as a substitute when she is about to be deprived of his presence. In response, Christ presses his face on a cloth and leaves an impression of his features: a true image (see PI, p. 207). This legend eventually merged with another legend, that of the holy shroud, perceived as a vera eikon (whence derives the name Veronica). Yet, whereas a subjective vision might easily lead to aesthetic contemplation, the Buddhist desire for vision is not purely assertive: the beholder wants also to be beheld, to dwell in the benefic, transformative gaze of the icon. The icon is also at the center of meditation (dhyanna, "visualization"): here too we have a form of image making, one that results in a mental icon. ${ }^{38}$

The intimate relationship between the icon, the god, and the believer can also be observed in China and Japan in the cases of people who, in times of drought, attempt to coerce the deity by making its icon suffer from exposure to the sun, or by throwing the icon into the water because the god has failed to protect them from a disease. ${ }^{39}$ In some of

35. Lewis R. Lancaster, "An Early Mahāyāna Sermon about the Body of the Buddha and the Making of Images," Artibus Asiae 36, no. 4 (1974): 289.

36. See Höbögirin, s.v. "Butsuzō." For this story, see also John S. Strong, The Legend of Upagupta: Sanskrit Buddhism in North India and Southern Asia (Princeton, N.J., 1992), pp. 104-17.

37. See the rendition of Divyävadāna in Ananda K. Coomaraswamy, The Transformation of Nature in Art (New York, 1934), p. 102.

38. On the "visualization" of images according to Buddhist scriptures, see Demiéville and Émile Benveniste, "Note sur le fragment sogdien du Buddhadhyānasamädhiãgarasūtra," Journal Asiatique 223 (Oct.-Dec. 1933): 193-248.

39. On this point, see Alvin Cohen, "Coercing Rain Deities in Ancient China," History of Religions 17 (Feb.-May 1978): 244-65. 
these stories, the god appears subsequently in the dreams of other monks to complain about this harsh treatment. ${ }^{40}$ At any rate, the icon seems to offer a direct access to the god and to allow for all kinds of spiritual blackmail or hostage taking.

The "true images" (zhenxiang or chinzō), portraits of Chan/Zen masters that have long aroused the interest of art historians because of their so-called realism, must be understood against their funerary backdrop. ${ }^{41}$ This is not true, of course, of all Buddhist icons, strictly speaking. In Chinese, the term used to qualify powerful icons, ling (usually translated as "power" or "efficacy"), generally connotes death. ${ }^{42}$ Even in the case of icons such as those deriving from the image made by King Udayana, one could perhaps argue that Sākyamuni's departure to the Trāyastrimśa Heaven was a kind of anticipation of his great departure into nirvana. In this sense, the image is not so different from a chinzō; each is a vera eikon, a true image.

There appear to be some exceptions. For instance, a distinction may be drawn between images used as aids for meditation and images that serve as channels of power in a cultic context. At first glance, a visual aid for meditation seems to have little to do with death. But perhaps the cultic logic at work in these, too, has something uncanny about it, and as this is the case, the funerary chinzo can be taken as paradigmatic for this sort of image, as well. The funeral of the Chan master is reminiscent of what the Romans called a funus imaginarium, an "imaginary" funeral, or, more precisely, a "funeral for an imago," in which the portrait of the deceased takes the corpse's place ${ }^{43}$ Florence Dupont points out that the imago "is the trace, not the figuration, of the deceased.... This presence is real, and has nothing to do with the presence/absence of images that merely resemble him." ${ }^{4}$

40. See, for instance, in the Jingde chuandenglu (Record of the Transmission of the Flame in the Jingde), the story of the "mad monk" Shide, who beats up a monastery god for seeming unable to protect the monastery (Taishō shinsh $\bar{u}$ daizōkyō, 51:434a); or, in Mangen Shiban, Enpō dentōroku (Record of the Transmission of the Flame in the Enpō; 1706), the case of the Zen monk Kyōō Unryō (1267-1341), who threw the mountain god of Hakusan into a pond after this deity had failed to protect his community from an epidemic (see Enpō dentōroku in Dai Nihon bukkyō zensho, ed. Takakusu Junjirō et al., 150 vols. [1931; Tokyo, 1970-73], 108:212a). Incidentally, the fact that not only children but also adults are affected (although in different fashions) by the violence done to inanimate figures was brought home to me on the occasion of my daughter's birthday as I watched the beating of a piñata.

41. See Foulk and Sharf, "On the Ritual Use of Ch'an Portraiture in Medieval China."

42. To give just a couple of examples, a lingwei is a tablet placed in front of the coffin, a lingwu, a paper house burned at funerary rituals.

43. Florence Dupont, "The Emperor-God's Other Body," in Fragments for a History of the Human Body, ed. Michel Feher, Ramona Nadaff, and Nadia Tazi, 3 vols. (New York, 1989), 3:403.

44. Ibid., p. 413. Although we are dealing with a different context, it is particularly interesting that the term representation, in French royal funerary rituals, means a catafalque, 
The theme of the animation of the icon is found across times and cultures, from Pygmalion to Chinese painters like Gu Kaizhi, who lived in the fourth century. ${ }^{45}$ It accounts for the liveliness, or potential for liveliness, of images. The effects of this animation can sometimes remain invisible, but can sometimes also be quite dramatic, as in the following account from the biography of the Tantric priest Vajrabodhi:

The Emperor ordered Vajrabodhi to set up an altar in order to pray for rain. Vajrabodhi thereupon called on Amoghāṅkuśa, according to the bodhisattva ritual, and erected an altar. ... He himself painted an image of the Bodhisattva of Seven Kotis [that is, Guanyin], and set the date to "open its eyes," so that at dawn of that day it would rain.... On the seventh day, the air was hot and dry; there were no clouds in the sky. But in the afternoon when the eyes [of the statue] were opened, a northwest wind immediately began to blow. Tiles flew off roofs and trees were uprooted. Thundering clouds burst forth with rain, startling those near and far. And in the place of the altar, a hole broke through the room so that the ritual arena was deluged. The next morning, gentlemen and commoners of the capital all said, "Vajrabodhi captured a dragon which broke out of the room and flew away." Hundreds of thousands of people daily came to look at the place. Such is the divine efficacy of the "altar ritual." 46

Likewise, we are told that the dragon paintings of Fuxing were used to make the rain fall, while the lion paintings of Puyangcheng healed people afflicted with malaria.

The animation process of Buddhist icons corresponds to what the Greeks called stoicheiosis, in which talismanic powers are brought to an icon through the introduction of mineral or vegetal substances, or even sometimes of small animals (lizards), but also through inscribed seals or incense. ${ }^{47} \mathrm{It}$ is at times difficult to distinguish between relics and ex-votos inside Buddhist icons. But the placing of relics inside an icon is not everything. More fundamentally, icons are alive because they have been consecrated. This also explains why they can, and in some cases must, be desecrated. The iconoclast's attempt to destroy the icons is still an acknowledgement of their power, an affirmation qua negation. This kind

a funerary effigy. On this question, see Ralph E. Giesey, The Royal Funeral Ceremony in Renaissance France (Geneva, 1960).

45. According to Audrey Spiro, Gu Kaizhi's famous line on dotting the eyes of a portrait ("'What conveys the spirit and portrays the likeness lies precisely in these dots") must be understood in the context of ritual empowerment (Audrey Spiro, "New Light on Gu Kaizhi: Windows of the Soul," Journal of Chinese Religions 16 [Fall 1988]: 1).

46. Zanning, Song gaosengzhuan, in Taishō shinshü daizökyō, 50:711c. An earlier translation of this biography may be found in Chou Yi-Liang, "Tantrism in China," Harvard Journal of Asiatic Studies 8 (1944-45): 276-77.

47. On this question, see Strickmann, Mantras et mandarins, pp. 165-211. 
of desecration seems fundamentally different (or is it?) from the Western profanation described above. And if, in some cases, it can be seen not only as a response to but also as part of the icon's power, should we speak of the icon's masochism?

Many characteristic features of the Buddhist icon-consecration and insertion of relics, for example-are found traditionally in the Western tradition, too. This does not mean that we can project into Buddhism a Western, Christian metaphysics of presence but rather that there are some phenomenological constants in the human response to images. Sometimes Buddhist mummies, too, were used just like icons, as when the "flesh-body" of the Chan patriarch Huineng (d. 713) was paraded through town on a palanquin in times of drought, as a substitute for the icon of the Bodhisattva Guanyin. The description of this "celebrated monster" given by Jesuit missionaries suggests that, like popular icons, this mummy had been blackened by the smoke of incense. ${ }^{48}$ This raises the question of whether this flesh-body is the same as the lacquered, golden-colored mummy that was until recently visible at the Nanhua Monastery near Canton. It seems that one may discern in Buddhism two notions of presence, which perhaps entail two different conceptions of the sacred: the presence of the here/now (the immediacy advocated by "sudden" Chan/Zen), and the presence/absence of the sacred divinity (implying some form of mediation).$^{49}$ At any rate, it is clear that the notion of presence is not merely a Christian one, inspired by the eucharist and Byzantine icons; it is pre-Christian, or pagan-and nowadays eminently poetical.

In his stimulating work, Freedberg asks, "Why do we ignore the evidence for the effectiveness and provocativeness of images?" (PI, p. 26). There is perhaps no need to dwell here on what is apparently the blind spot of traditional Buddhist art history as well. T. Griffith Foulk and Robert $\mathrm{H}$. Sharf have pointed out some of the inadequacies of the aesthetic approach in the case of Chan/Zen portraiture, and, as already noted, recent Euro-American art history has become interested in the ritual "effectiveness" of images. Instead, I would like to explore what kind of possibilities arise when we consider icons as images of power-an expression that translates quite appropriately the Chinese term lingxiang (if

48. Here is how Father Longobardo describes a drought that plagued the inhabitants of the Guangtong province: "So they gave up hope in the city gods, and for the occasion they brought in a celebrated monster from the country. Its name was Locu [read Luzu, the Sixth Patriarch, that is, Huineng]. They paraded it about, bowed before it and made offerings to it, but like its counterparts it remained deaf to their pleading. It was this occasion that gave rise to the saying, 'Locu is growing old"' (Matthew Ricci, China in the Sixteenth Century: The Jourmals of Matthew Ricci, 1583-1610, trans. Louis J. Gallagher [New York, 1953], p. 425).

49. On the Chan "rhetoric of immediacy" and the central role of mediation, see Faure, The Rhetoric of Immediacy. 
perhaps less clearly its Japanese counterpart, reizō)-and to discuss, as Freedberg and others have done for Western art, the possibility of a theory of response. This means attempting to free ourselves from the obsession with meaning (symbolism, iconology in the Panofskian sense) and form (style) in order to retrieve the affect, effectivity, and function of the icon. ${ }^{50}$ We need to go beyond the traditional concerns about the genesis of particular works of art; influences; attempts to retrieve historical or aesthetic categories (the sublime, and so forth); and, more generally, the privileging of "high" art.

Because he deals with Western materials, Freedberg is concerned mainly with the extreme eroticism of images, a dimension that one might claim is less conspicuous in Buddhist or Asian images. Indeed, it seems more difficult to derive a "phenomenology of coprophilia and arousal" from the vast bulk of Buddhist sculpture-with the exception of some Tantric figures (PI, p. 20). Many scholars would probably argue that even in these cases the image should be seen as merely a symbolic expression of the philosophical "conjunction of opposites" and not as a realistic representation of carnal lust. Even if the point were granted, it is obviously clear that such dialectical images lend themselves to a multitude of interpretations. Likewise, even if repressed in terms of pictorial depiction, the development of a motif such as that of Guanyin as prostitute, an illustration of this bodhisattva's vow to appear in the world to save beings overcome by desire, must have had a power of arousal that we no longer suspect. The same can be said of figures of goddesses like Benzaiten or Kichijōten, or of the representations of Mañjuśrī, Shōtoku Taishi, and Kōbō Daishi as young boys (chigo). ${ }^{51} \mathrm{~A}$ similar example, in the Christian context, would be the popular image of the Virgin offering her breast to a sick monk. If this male fantasy was triggered by the monastic contemplation of an icon, one might expect the same fantasies to have arisen from Buddhist monks' relations to Guanyin and other similar (male or female) figures.

"Seeing comes before words," John Berger argues. ${ }^{52}$ Yet our gaze is always already informed by words, discourse-discursive thought, a thinking whose course is dual, bifurcated. There is no need to further

50. As Jean-François Lyotard puts it: "This is the way philosophers enter the stage of 'criticism,' by way of this gap through which the work escapes being converted into meaning" (Jean-François Lyotard, "Philosophy and Painting in the Age of Their Experimentation: Contribution to an Idea of Postmodernity," trans. Mária Minich Brewer and Daniel Brewer, The Lyotard Reader, ed. Andrew Benjamin [Oxford, 1989], p. 182).

51. For an "art historical" presentation of some of these boyish figures, without discussion of their power of sexual arousal, see Christine M. E. Guth, "The Divine Boy in Japanese Art," Monumenta Nipponica 42 (Spring 1987): 1-23. For a discussion of Buddhist pedophilia, see Faure, The Rhetoric of Immediacy, pp. 248-57. For a discussion of the homoerotic tradition of Western humanism through the figure of Ganymede, see Leonard Barkan, Transuming Passion: Ganymede and the Erotics of Humanism (Stanford, Calif., 1991).

52. John Berger, Ways of Seeing (1972; London, 1977), p. 7; hereafter abbreviated WS. 
emphasize the importance of the gaze, not only in the Indo-Buddhist tradition, but also in the Western tradition. As the conscious gaze, presupposing spacing and differentiation, is always already mediated by discourse, apparently no primacy of perception exists. Although words can never replace seeing, seeing is already informed through knowledge, discourse, and words, and our discourse on Buddhist "art" is itself informed by several venerable traditions.

Even when we attempt to break away from the traditional aesthetic approach to take into account the anthropological or cultic dimensions of the Buddhist icon, our predominant influence remains Western. Whatever its inadequacies, the study of the anthropological or cultic dimensions of Buddhist art appears as a prerequisite, an antidote to the dominant Orientalist and/or aesthetic approaches. As Heidegger puts it, "the works [of art] themselves stand and hang in collections and exhibitions. But are they here in themselves as the works they themselves are, or are they not rather here as objects of the art industry? ${ }^{53} \ldots$ The whole art industry, even if carried to the extreme and exercised in every way for the sake of works themselves, extends only to the object-being of the works. But this does not constitute their work-being." ${ }^{44}$ Of course, there are also ambivalent cases, for instance in modern Japan, where icons are at the same time-although not for the same people-objects of collection and of devotion, of aesthetic appreciation and of religious respect.

If icons, in their ritual context, are essentially traps, devices for capturing power (ling), it is no wonder that the art historians, but also the artist-monks, like the gods of their iconology (or iconography), would be in turn trapped by their lure (what the French call a miroir aux alouettes). ${ }^{55}$ Our discussion of the nature of the icon should blur the opposition between presentation and representation: both are always present, and interpretation is always to double business bound. And yet the icon is neither simply presence nor representation.

We stand at the intersection of several strands (aesthetic, philosophical, and cultic) of the Western and Asian traditions, which are themselves dual, insofar as they present iconic (or cultic) tendencies and iconoclastic rhetorics-a duality found most notably in Chan/Zen Buddhism. Insofar as it acknowledges its debt to Asian and Western, Buddhist and Christian traditions, while attempting to intertwine them, my own discourse here is self-consciously and painfully hybrid. However, before weaving these various strands into a new pattern, I should try to disentangle the red thread that runs through each of them.

53. The German Kunstbetrieb could be translated, more literally, as "bustling activity around art."

54. Martin Heidegger, "The Origin of the Work of Art," Poetry, Language, Thought, trans. Albert Hofstadter (New York, 1971), pp. 40-41; hereafter abbreviated "OW."

55. See Faure, Visions of Power, pp. 224-74. 
In Christianity, the belief in the incarnation, while an attempt to make "the invisible visible," amounted to a destabilization of the visible, its opening into-or rather, its escaping, vanishing unto-another, still invisible, reality. The vanishing point in question, however, is not that of perspective. Although the manifestation of the Buddhas and bodhisattvas in this world is not the same thing as the incarnation of Christ, there is something to be learned from the history of Western images. I say "Western images," not "Western art," because the latter could be seen, at the risk of oversimplifying, as a forgetting of the incarnation of the invisible in the visible, just as Western philosophy, according to Heidegger, is a forgetting of the Greek notion of Being as "appearing" (Erscheinen). ${ }^{56}$ In the Buddhist context, an example of that paradoxical attempt to reveal the invisible is the wooden image of the Chinese thaumaturge Baozhi (418-514), in the Kyoto National Museum. The face of this icon splits open, like a dehiscing fruit, and another face, that of Dizang, the bodhisattva who was Baozhi's true nature, appears within (behind the mask). The story behind that image is also revealing: we are told that the artist who tried to represent Baozhi found it impossible to fix his features because they changed constantly.

Another symbolic expression of the excess that constitutes the unrepresentable is the invisible usnis $a$ or fleshy protuberance on the top of the Buddha's head. We are told that this usnīsa remains invisible because no one can look down on the Buddha. On the one hand, it is but one of the thirty-two signs that configure the Buddha's body, obfuscating it while revealing it. On the other hand, it is a paradoxical, formless sign that implies its own negation. ${ }^{57}$ According to Stella Kramrisch, it constitutes "an extension of the body-like appearance of the Buddha beyond its anthropomorphic limits" (EI, p. 131). ${ }^{58}$ The uṣnișa is the unseen top of the Buddha icon, symbolizing its nirguna, or unqualified aspect, the paradoxical quality of the supramundane or transcendent Buddha. It is, as it were, the invisible top of a truncated column-like the one in Giorgione's Tempesta, a comparison to which we will return.

The point is this: something appears in the icon that is beyond representation, and this something projects the whole icon beyond representation. It interrupts or doubles the convenient demarcations of aesthetic, artistic, symbolic, or art-market economies. The icon is at the same time here and there, bridging the gap between two realms and partaking of

56. Heidegger, An Introduction to Metaphysics, trans. Ralph Manheim (New Haven, Conn., 1959), p. 98.

57. Another practically invisible mark of the Buddha has caught the Buddhist imagination: his hidden reproductive organ; his sheathed, as it were, "invaginated" penis, which is often compared to that of a horse or an elephant.

58. In Chan/Zen, the term uṣnișa (in Chinese, dingxiang; in Japanese, chinzō) came to designate the portrait of an enlightened abbot. On this question, see Foulk and Sharf, "On the Ritual Use of Ch'an Portraiture in Medieval China," pp. 202-6. 
both. To begin to understand this paradoxical presence or visuality, we need to expand our visual field to include in it other realities, such as dreams, visions, relics, and rituals. In this sense, images (unlike art) belong to the field of anthropological history and no longer to art history alone. Here Georges Didi-Huberman's notion of the visual (as opposed to the merely visible) proves heuristically useful. According to DidiHuberman,

there is no image that can be thought radically except beyond the principle of visibility, that is, beyond the canonical oppositionspontaneous, unthought - between the visible and the invisible. This beyond will still have to be called visual, as that which will always come to create a flaw in the disposition of seeing subjects to reestablish the continuity of their descriptive recognition or of their certitude with respect to what they see. ${ }^{59}$

The visual is what, in the visible, modifies it and gives it its character of sacred event, what connects metonymic figures of the double like icons, relics, and dreams.

In their attempt to move away from discussions about the sublimity of art, art historians have tended to focus on works of art as "deposit[s] of a social relationship" or "fossils of economic life." 60 Alternatively, they have focussed on symbolism (Panofsky's iconology) or on techniques of production. Recent scholarship has explored, for instance, the technical aspects of the manufactured object-what Heidegger described as the artisanal element of the work of art. Heidegger warns us that "the muchvaunted aesthetic experience cannot get around the thingly aspect of the art work," but at the same time he wants to retrieve what, apart from materiality, defines the work of art ("OW," p. 19). However, when the focus is on the object (as "thing" or as "work"), there is a danger of missing or minimizing the response of the subject (the beholder). Even when the emphasis is on the response to art, this approach does not always sufficiently address the nonaesthetic effects that images may have on the beholder, and, in particular, the performative function they have in a

59.

Il n'y a d'image à penser radicalement qu'au-delà du principe de visibilité, c'est à dire au-delà de l'opposition canonique-spontanée, impensée-du visible et de l'invisible. Cet au-delà, il faudra encore le nommer visuel, comme ce qui viendrait toujours faire défaut à la disposition du sujet qui voit pour rétablir la continuité de sa reconnaissance descriptive ou de sa certitude quant à ce qu'il voit. [Didi-Huberman, Ce que nous voyons, ce qui nous regarde, p. 76]

See also Didi-Huberman, Devant l'image.

60. Michael Baxandall, Painting and Experience in Fifteenth-Century Italy: A Primer in the Social History of Pictorial Style (Oxford, 1972), pp. 1, 2. 
ritual context. If, following Kramrisch's discussion of the Buddha's bodily marks, we admit that the uṣnișa stands for the sublime or for transcendence, whereas the web symbolism on the Buddha's body stands for immanence, the inscription of the icon in multiple symbolic networks, then one could argue that the gaze of the icon, but also its touch, usually forgotten in these discussions, establish another type of communication-of relationship-between the icon and its beholder (its would-be holder, but also its beheld and beholden believer). Some of these icons, like those of Binzuru (that is, Pindola, an arhat famous for his magical powers) are called in Japan nade-botoke ("Buddha to stroke"). Others are kept, on the contrary, off-limits, because they are too powerful; they tend to get out of hand, or cannot be touched without harm. It is often one of their lesser manifestations that is offered to the touch or gaze of worshippers.

We need therefore to look again at traditional themes of Buddhist art, such as the vexed question of iconism and aniconism, the iconoclastic rhetoric of Chan, the double and the symbol, and ritual efficacy. The icon (and, more broadly, the symbol) permits an articulation between different symbolic orders (the stupa, the human body, the social body, the cosmos). Such an articulation is not, however, a pure equivalence because these various orders remain clearly distinct; the family resemblance between various symbolic artifacts should not be construed as an identity. There is a constant danger of hermeneutic overkill: an icon is not a mummy, which is not a living being. Yet something circulates from one to the other, a circulation permitted by a certain isomorphism, isotopy, mimesis, and functional equivalence between these figures of the double. There is no identification, at least as long as a clear sense of boundaries, what Nietszche would have called an Apollinian sense, prevails-but this sense is at times erased, during crepuscular moments of Dionysian high tide, the time of ritual when all sacred cows and all cats turn grey.

When we try to retrieve this dialectical dimension, how can we avoid the double pitfall of formalism and historicism? Iconological interpretation, despite (or because of) its sophistication, tends to hermeneutic overkill. At any rate, trying to understand the symbolic motivation of the artist is not sufficient, because, as Dan Sperber has pointed out, this motivation is itself symbolical.$^{61}$ We need to go beyond a purely semiological reading, or beyond reading as such, that is, beyond interpreting the image as a message, a symbol (in the traditional sense). Only then can we understand the symbol (in the etymological sense of "throwing together"). This long detour from one type of symbol to another only has the appearance of a tautology, of a vicious, or, if you prefer, hermeneutic, circle. Actually, it is not so much a circle as a recycling of old ideas, putting them to new use. This whole discussion may seem rather obvious to postmodern

61. See Dan Sperber, Rethinking Symbolism, trans. Alice L. Morton (Cambridge, 1975), p. 33. 
historians, but Buddhist art history still has a long way to go before earning the dividends (and enjoying the divisiveness) of postmodernity.

For this bricolage, we find in the toolbox of Western art criticism, beyond a traditional aesthetic criticism of a rather descriptive vein, various recent theoretical attempts at "thinking through" the icon with concepts such as the fetish (Marx); the aura (Benjamin); the visual (DidiHuberman); the parergon (Derrida); the effigy (Louis Marin, Jean-Pierre Vernant); or the symbol, perceived, in the words of Jean-Joseph Goux, as a concrete union between the finite and the infinite. ${ }^{62}$ Paradoxically, we might also try to retrieve some submerged or peripheral intuitions of Kantian or Hegelian aesthetics (most notably the Kantian discussion of the sublime and the colossal) or take our cues from Baudelaire, who wrote: "Praise the cult of images (my great, my unique, my primitive passion)." ${ }^{63}$ But this means that we attempt to divert these concepts from their classic use, to subvert them by dislocating and relocating them, not that we simply yield to the grandiloquence of sublime aesthetics. To us, sublime resonates with sublimation and with subliminal.

In his analysis of Eisenstein's film images, next to (or rather beyond) their semiotic and symbolic meanings Roland Barthes distinguishes a "third meaning" (playing on the polysemy of the French word sens: "meaning," "signification," but also "sense," and "direction"). ${ }^{64}$ He returns to this theme, in regard to music, with his notion of the grain of the voice: "Through music, we understand better the Text as significance [as opposed to mere 'signification']." ${ }^{5}$ If so, through what medium can we understand better the "image as significance"? Significantly, this "third meaning" is qualified as obtuse (as opposed to obvious). What I am trying to retrieve in Buddhist icons seems akin to what Barthes calls the obtuse meaning, only it is no longer a meaning, strictly speaking, but rather an elusive reality, perhaps akin to the perlocutionary aspect of language according to Austin, or to what in Indian aesthetics is called the indirect (paroksa) and in Buddhism "twilight language."66

62. Jean-Joseph Goux, Symbolic Economies: After Marx and Freud, trans. Jennifer Curtiss Gage (Ithaca, N.Y., 1990), p. 67. See also Karl Marx, Capital: A Critique of Political Economy, trans. S. Moore and E. Aveling, ed. Friedrich Engels, 3 vols. (New York, 1967); "WA"; Derrida, The Truth in Painting, trans. Geoff Bennington and Ian McLeod (Chicago, 1987), chap. 1, hereafter abbreviated TP; Louis Marin, The Portrait of the King, trans. Martha Houle (Minneapolis, 1988); and Jean-Pierre Vernant, Myth and Thought among the Greeks (London, 1983).

63. "Glorifier le culte des images (ma grande, mon unique, ma primitive passion)" (Charles Baudelaire, "My Heart Laid Bare," "My Heart Laid Bare" and Other Prose Writings, trans. Norman Cameron, ed. Peter Quennell [New York, 1975], p. 198).

64. Barthes, "Introduction to the Structural Analysis of Narratives," pp. 43-58.

65. Ibid., p. 277.

66. See J. L. Austin, How to Do Things with Words (Cambridge, Mass., 1962). On the indirect, see Coomaraswamy, The Transformation of Nature in Art, pp. 121-38; on "twilight language," see Roderick S. Bucknell and Martin Stuart-Fox, The Twilight Language: Explorations in Buddhist Meditation and Symbolism (New York, 1986). 


\section{The Stupendous Icon}

Fenollosa saw the introduction of Buddhism to China as a "stupendous revolution" in Asian art $(E C, 1: 28)$. Let me indulge in an etymological fantasy and derive stupendous from stupa (as colossal derives from kolossos, an erected stone). One could argue that Buddhist art begins with a stupa, a funerary monument usually seen as a symbol of death but that is also a symbol of life and fertility. As is well known, the stupa gave birth to the Chinese pagoda (a term said to derive from dagoba, a contraction of dhätu garbha, "womb of the relic"). According to Hegel, the origin of the Indian icon is to be found in the linga, a column that resembles the ovoid or seamless stupa (an egg-shaped monument, distinct from the fivedegree stupa) of Japanese Buddhism. ${ }^{67}$ This phallic column is soon ornamented with images emptied and hollowed out by these supplements. Asian art thus evolves from the column; the linga is emptied to produce icons. Speaking of the culture of Angkor, Georges Coedès writes: "The essence of kingship was supposed to reside in a linga ensconced in a pyramid in the center of the royal city, itself supposed to be at the ideal center of the world. The cult of the god-king was first introduced in the ninth century. Later, with the introduction of Buddhism, the god-king became an image of the king as Buddha." ${ }^{8}$ The truncated column, like Mount Sumeru, the cosmic pillar whose upper part vanishes into the thin air of higher realms, is therefore the image or symbol of the symbol itself. Likewise, the portrait (chinzō) of a Chan/Zen master, a variant of the Buddha icon, is a truncated column, whose top (usnissa, the skull protuberance, translated as chinzōo) is invisible. Needless to say, I do not have in mind here an evolutionary conception of art like that of Hegel. I merely want to suggest that there may be more than meets the eye in this Hegelian column. This emphasis on phallic imagery should not be read too quickly as standard phallocentrism, since the column is also a crypt. Its hollowness and the womb symbolism that accompanies it deflate its apparent turgescence, or at least belie its gender symbolism. ${ }^{69}$ Segalen, too, saw the origin of Chinese statuary in the column and the stele. Stupas and steles are perhaps the Asian counterparts of the Greek kolossos.

The Hegelian conception of the column/linga and its relation to images recalls, mutatis mutandis, Kramrisch's description of the Hindu temple or Paul Mus's discussion of the Buddhist stupa. One can say of

67. Whereas the five-degree or "five-wheel" stupa symbolizes the five elements of the Buddhist cosmos, the ovoid or seamless stupa represents the pre- or postcosmic stage, the stage of indifferentiation and chaos before the emergence of the symbolic.

68. Coedès, Pour mieux comprendre Angkor, p. 62.

69. On the symbolism of turgescence and the "phallic effect that is not necessarily specific to the male," see Derrida, "Foi et savoir: Les Deux Sources de la 'religion' aux limites de la simple raison," in La Religion, ed. Derrida and Gianni Vattimo (Paris, 1996), p. 63. 
the Buddhist stupa and its relics what Kramrisch says of the Indian temple and its image- - the symbol or image occupies the center of the sanctuary and is known as the jiva, the 'life' of the temple in which it dwells.... The walls are its body" (EI, p. 253). While the center is unchanging, undifferentiated, like the immutable essence (purusa), the periphery is differentiated in its images, and changing, like matter (prakrti). We must, at least, distinguish between the static image at the center and its mobile counterparts at the periphery as they are seen in the ritual process, the hermeneutical circle of circumambulation. Thus, the stupa is, in more than one sense, an animated monument, not only because of the presence of relics that give it life but because of the procession of pilgrims that turns it into what Mus called a "cinetic" monument. ${ }^{70}$ The center/periphery, or inside/outside pattern overlaps with the nirguna/sarguna, or formless/with form paradigm. This paradigm is played out in a variety of ways in Hinduism and East Asian Buddhism: it informs, for instance, the distinction between the seamless or ovoid stupa and the fivedegree stupa in Japanese Buddhism.

In China, the mummies of Buddhist priests, first encrypted under the funerary stupa, eventually were placed in chambers at the entrance of the stupa, where they could reveal themselves on occasion to the bemused gaze of the worshippers-like the Buddha Prabhütaratna in the Lotus Sütra, appearing in midair within his stupa. One case in point is that of the mummy of the fourth Chan patriarch, Daoxin: the gates of his stupa opened by themselves, revealing his intact body in its eerie splendor, and no one afterwards dared to close them. I have examined elsewhere the process of iconization that brought these mummies out of their crypts into the "Image Halls" of Chan monasteries. ${ }^{71}$

We might pursue these philosophical musings on the column/stupa by turning to Kant's conception of the sublime as a truncated column, and to Derrida's analysis of the Kantian sublime in terms of the colossal and the parergon. The question of taille, size, is also that of taille, cutting, engraving. The French word taille derives from tailler ("to cut," "to engrave," "to carve"), hence the height of the human body (used by image carvers). Unfortunately, the English language does not allow us to follow Derrida in his wordplay on the limit that simultaneously delimits and "illimits." A "detail" (détail, or détaille)—like the visible/invisible uṣnișameans "the movement from cise [taille], which is always small or measured, to the disproportion of the without-cise [sans-taille], the immense. The dimension of the effigy, the effigy itself would have the fictional effect of demeasuring. It would de-cize [elle détaillerait], would liberate the ex-

70. Mus, “Civilisations d'Extrême-Orient," Annuaire du Collège de France 54 (1954): 238.

71. See Faure, The Rhetoric of Immediacy, pp. 148-78; see also Sharf, "The Idolization of Enlightenment." 
cess of cise" (TP, p. 121).$^{72}$ As Kramrisch points out, the Buddha image is always a cut above the human beings it seems to reproduce, and this excess (démesure) is in a sense the effect of its uṣnişa (see EI, pp. 130-40). Recall, too, that this term came to designate the portraits of Chan/Zen masters.

The logic of representation permitted by the icon is supplemented (in the Derridean sense, that is, also subverted) by the logic of impregnation that comes with the olfactive perception of incense. ${ }^{73}$ Do mummies and icons have a smell? ${ }^{74}$ They probably do, and this may explain why they are usually sealed with lacquer or gold. It may be worth mentioning here the case of the Central Asian thaumaturge Sengqie (d. 710), whose posthumous refusal to be enshrined in the capital-far from his community in Sizhou - was manifested in his corpse's stench. ${ }^{75}$ The mummy of the Chan master Wuliao (787-869) is another similar example, in which the stinking icon, the mummy, resists representation, resists commodity fetishism-even on the part of an Emperor. ${ }^{76}$ The icon fights back. The smell of the icon, whether stink or fragrance, is another excess, a sign of transcendence that can easily go unrecognized.

In this context, we may recall that the first Buddhist icons in Japan were made out of aromatic camphorwood (kusu), a particularly sacred wood, although especially difficult to carve. A good example is the Miroku image of Chūgūji, the first known instance of the assembled wood-

72. The translators of The Truth in Painting explain as follows their choice of cise for taille: "To render this second sense of the French taille, and to preserve the uncertainty between the two senses which is vital in some of what follows, we shall use the word 'cise,' an obsolete spelling of 'size' . . . and suggestive of cutting (cf. incision)" (TP, p. 120).

73. See Jean-Pierre Albert, Odeurs de sainteté: La Mythologie chrétienne des aromates (Paris, 1990), p. 232.

74. This question was raised by Janet Gyatso in her discussion of my book, The Rhetoric of Immediacy, and I owe this insight (or afterthought) to her. On the smell of death in art, see Mieke Bal, "Dead Flesh, or the Smell of Painting," in Visual Culture, pp. 365-83.

75. See, for example, this account in Fozu tongji (General Records of the Buddhas and Patriarchs): "When master Sengqie died, a royal decree ordered that his body should be lacquered and that a stupa should also be erected at the Jianfu Monastery. Soon after this, a foul smell pervaded the city. An edict ordered the body to be sent to [his former monastery at] Sizhou. At once, a fragrant breeze blew over the imperial capital" (Zhipan, Fozu tongji in Taishō shinshū daizōkyō, 49:372).

76. See the entry for Wuliao in the Fozu tongii:

Twenty years after its completion, [Wuliao's stupa] ... fell down owing to a flood in a hill stream. His disciples then saw that the corpse had suffered no physical deterioration. When the prince of the Min State heard this news, he sent a messenger and took the corpse to his house to worship. Immediately a bad smell came out of the corpse. After the prince had offered some incense and prayed, and it had been reenshrined at the original place at Guiyang, a fragrant smell came out soon after its restoration. So all the people of that city went out and paid homage to that stupa. [Ibid., 49:389] 
block technique (yosegi zukuri). It has been argued that camphorwood was the Japanese equivalent for sandalwood, out of which was carved the first icon of the Buddha. But, unlike sandalwood icons, camphorwood icons were usually painted, which tends to cover the fragrance. The Yumedono Kannon, for instance, is carved out of camphorwood. The fragrance of these icons may be seen as a reflection of the natural fragrance of the Buddha's body, but it may also be a way to cover the lingering stink of death in icons that were perceived as mummies or as anthropomorphic tombs containing relics.

\section{The Logic of the Tessera}

As Derrida has shown in his discussion of the parergon, the icon lends itself to deconstruction. It is both disjunctive and conjunctive, or, better, it itself operates the disjunction between disjunction and conjunction: the disjunction between, precisely, iconophilia and iconoclasm. Because of the appearance of the icon, two strategies become possible, or, rather, two poles are produced, with a number of intermediary strategies. The icon is also conjunctive, like the ritual centered on it, joining and separating the two spheres of the profane and the sacred, providing the ontological cut (la taille, "cise") and the scar. Derrida again:

Thus all this goes on around an infinite but truncated column, at the limit of the trunk, at the place of the truncation or the cutting edge, on the borderline, fine as a blade, which defines the cise. The question opens around knowing whether one must think a sublimity of the soul from one edge or the other, of the infinite or the finite, it being understood that the two are not opposed to each other but that each transgresses itself toward the other, the one in the other. $[T P, \text { p. } 134]^{77}$

I argued above for the need to go beyond traditional iconology, that is, beyond an approach that reads images as symbols. In apparent selfcontradiction, I want now to argue for considering the icon as a symbol, but a symbol in a different, etymological sense. Referring to John Skorupski's notion of the symbol as something that "in some sense is or participates in the reality it represents," Freedberg asks rhetorically, "If we speak thus of identity, what need for the notion of the image or object as sym-

77. See also the following: "This double trait of a cise which limits and unlimits at one and the same time, the divided line upon which a colossus comes to cise itself, incise itself without cise, is the sublime"; "the colossal is, in other words superelevates itself, on both sides of its own cise, it is on both sides its own cise, it is of its own cize on both sides. A priori and from the start double colossus, if not double column. Whence its resonance" (TP, pp. $144,145)$. 
bol?" (PI, p. 277). None, of course, unless we use the word symbol in its etymological sense of the identity and complementarity of tallies (doubles) - what I call the logic of the tessera. ${ }^{78}$ This logic of the symbol, or of the tessera, lends itself to duplication, that is, to the production or even the profusion of doubles. The duplication process is not simply the result of new techniques of production (icons constructed from many prefab pieces, versus one-piece icons, carved from a single block of wood or stone), although technical factors clearly played an important part in it. ${ }^{79}$

The Chinese tessera $(f u)$ was a bamboo tab or tablet divided longitudinally into two parts to serve as testimony in a contract. The term means, variously, a seal divided in two parts; to concord, to adjust, to respond mutually, to fit, or to conform; or a good omen, a charm (writing or drawing), an amulet, or a talisman. The compound fuhao denotes a symbol, a mark, a sign. Robert Des Rotours notes that these insignias or double contracts were of universal use. In France, they were called tailles because of the incision made on the two juxtaposed sticks; this is the origin of the English word tally. ${ }^{80}$

According to the Shuowen dictionary, "the $f u$ is what gives proof [ce qui fait foi]. In the Han regulations, one divides a six-inch-long piece of bamboo in order to join its two parts." The Cihai also defines fuxin as follows: "What is in the genre of insignia or tablets in two parts (fuqi) is also called fuxin, which means insignia used as proof [wei]." The word xin, which means "faith," or "worthy of faith," also means "seal," or "tessera." The Ciyuan has the following about fu: "A bamboo [tablet] on which characters were written; one divided this tablet into two parts, each person

78. After writing this, I came across a reference to the tessera in Michael Ann Holly's recent essay on Wölfflin. She writes: "The corpus of Wölfflin's work can be read according to the trope of tessera coined by Harold Bloom to explain the 'anxiety of influence' often 'suffered' by poets" (Michael Ann Holly, "Wölfflin and the Imagining of the Baroque," in Visual Culture, p. 351). And: "In Bloom's terms, Burckhardt's Renaissance provided the tesserae for Wölfflin's baroque" (ibid., p. 362). Here is Bloom's definition of the tessera: "I take the word not from mosaic-making, where it is still used, but from the ancient mystery cults, where it meant a token of recognition, the fragment say of a small pot with which the other fragments would reconstitute the vessel" (Bloom, The Anxiety of Influence: A Theory of Poetry [Oxford, 1973], p. 14). Yielding to the anxiety of influence, I add this fragment to my little vessel, although it may belong to another larger and more artistic one.

79. I owe this information to Mimi Yiengpruksawan.

80. See Robert Des Rotours, “Insignes en deux parties (fou) sous la dynastie des T'ang (618-907)," T'oung Pao 41 (1952): 34. See also the standard definition of the substantive tally, which includes the meanings "a reckoning or score"; "a stick on which notches are made to keep a count or score" or "a stick on which notches were formerly made to keep a record of amounts paid or owed"; "a mark used in recording a number of acts or objects, most often in series of five, consisting of four vertical lines canceled diagonally or horizontally by a fifth line"; and "something that is very similar or corresponds to something else; a double or counterpart."

81. Significantly, the same term was used in Chan/Zen for the definition of the patriarchal robe, which was the main emblem of transmission. 
kept one half. One reunited these two parts when one wanted to prove one's sincerity. Sometimes these were made of wood, jade or metal." ${ }^{82}$ According to the Cihai dictionary, $f u$ also has the meanings "good omen" and "amulet." It can in some cases play the role of a talisman. These insignia were used in a lot of administrative and judicial functions from the Han dynasty onward.$^{83}$ A synonym is $q i$, a tablet used for a contract, generally written on and divided into two parts. According to the Shuowen, a $q i$ is a large contract. The Cihai defines it as a contract or a diploma in two parts. The word derives from the Chinese for incise, engrave, hence it signifies also an incision (taille). ${ }^{84}$ These etymologies call to mind the old Chinese saying, "To incise the boat at the place where the sword fell in the water"-which is perhaps a nice metaphor for what we are trying to do when we judge Buddhist icons by modern standards, whether those of art history or of anthropology.

On the Western side, we use the term symbol, derived from sumbolos (and sumballein, "to throw together") (see, for instance, "OW," p. 20). An equivalent term is token, a piece of stamped metal used as substitute for currency - therefore halfway between false and real money. What affects the prototype of the image during the ritual also affects the beholderby the same token, because they have the same token, the same "counter." The response (ying) of the deity is the counterpart of the response of the follower. Ultimately, the Chinese symbol is not simply a juxtaposition of two tallies; it is a union, a hierogamy-which implies an exchange of substance, a twofold movement, upward and downward. The logic of this kind of symbol is not simply metaphoric but also metonymic.

Icons can be used as material objects of worship or as mental aids for meditation through visualization. However, the distinction is by no means clear-cut: visual icons, just like material ones, are essentially "traps for power," and they function as substitute bodies. This power can at times be nefarious, as with the straw dogs of Chinese antiquity, ritual

82. Des Rotours, “Insignes en deux parties (fou) sous la dynastie des T'ang (618-907)," p. 5 .

83. Before the Tang, they had the shape of a tiger; during the Tang, usually that of a fish, sometimes of a tortoise. Until the Tang, the inscription was written on the edge, before the insignia was slit; later it was written on each side of the fault line; finally it was written inside the insignia, while the characters hetong, engraved on the edge, are split in the middle and must be reconstituted when the two parts of the insignia are reunited. In some cases, the inscription inside, reading tong ("same"), carved in relief (yang) on one side, must also fit together with the text carved en creux (yin) on the other side. So one part of the $f u$ was kept inside the palace, the other (or others, for there were sometimes as many as twenty) were distributed to functionaries, who were sent to the provinces. After the Song, they were replaced by tablets (pai)_-but their symbolic value (in both senses) remained.

84. Among the various meanings for $q i$ we find "pact, contract, convention; to carve, to incise; to concord, to match, to agree." This term is also used to designate awakeningtallying with truth-and Chan transmission-tallying between master and disciple, between mind and mind. 
scapegoats that were ritually destroyed; or the Japanese dolls that are given to the custody of temples (like the Ningyō-dera, "Doll Temple," in Kyoto). The same is true of mental images of demonic powers, which are summoned by the practitioner to be eliminated through incantations or imaginary battles.

In traditional Buddhist practice, the meditator must visualize the physical attributes of a Buddha to obtain the "samadhi [mental absorption] of the one who stands (avasthita) face-to-face with or in the presence of (sammukha), the present . . Buddhas." ${ }^{85}$ One of the sixteen ways to obtain this samädhi is by having an icon of the Buddha made, or "just having a picture painted." 86 One of the raisons d'etre of the first image of the Buddha was to aid contemplation during the time when the Buddha would no longer be on earth, and looking at it is said to be "no different from looking at the Buddha's [actual] body." Significantly, among such visual aids, Chinese Buddhists included paintings of landscapes. Stein has shown that the miniature landscape, perceived as a microcosm, constitutes a kind of tally. This world in miniature is said to call the powers of the macrocosm, which flow into it, fusing with it. Like the icon, the bonsai is a trap for power; it was used in particular by the Daoist ascetics to increase their longevity. ${ }^{87}$ Originally, as Delahaye has shown, landscape painting had a talismanic value not so different from that of the Daoist "sacred maps." This explains why these paintings, despite secularization, have remained "compelling images" in the hands (and eyes) of the literati, a facet of aestheticism that would probably surprise many connoisseurs of Chinese art. ${ }^{88}$

\section{The Aura of the Icon}

An analysis of Buddhist icons would not be complete without a discussion of Benjamin's seminal notion of the aura of the work of art. ${ }^{89}$ Such a reference is not merely a nod in the direction of modern art criticism; indeed, this notion turns out to be quite useful in defining the obtuse

85. Paul M. Harrison, "Buddhānusmrti in the Pratyutpanna-Buddha-SammukhāvasthitaSamādhi-Sūtra," Journal of Indian Philosophy 6 (Sept. 1978): 42. See also Miranda Shaw, "Buddhist and Taoist Influences on Chinese Landscape Painting," Journal of the History of Ideas 49 (Apr.-June 1988): 196.

86. Harrison, "Buddhānusmrti in the Pratyutpanna-Buddha-Sammukhāvasthita-SamādhiSütra," p. 39.

87. See Rolf A. Stein, The World in Miniature: Container Gardens and Dwellings in Far Eastern Religious Thought, trans. Phyllis Brooks (Stanford, Calif., 1990), pp. 5-48.

88. See also Delahaye, Les Premières Peintures de paysage en Chine: Aspects religieux (Paris, 1981), and James Cahill, The Compelling Image: Nature and Style in Seventeenth-Century Chinese Painting (Cambridge, Mass., 1982).

89. Aura - "souffle"-is not, like aureole, derived from aureus, "golden [crown]." 
presence of the icon. In "The Work of Art in the Age of Mechanical Reproduction" (1936), which appeared the year after Mus published Barabudur, Benjamin defines the aura of natural objects as "the unique phenomenon of a distance, however close it may be" ("WA," p. 222). This notion is then extended to cultural (and cultic) productions. In a footnote, Benjamin adds:

The definition of the aura as a "unique phenomenon of a distance however close it may be" represents nothing but the formulation of the cult value of the work of art in categories of space and time perception. Distance is the opposite of closeness. The essentially distant object is the unapproachable one. Unapproachability is indeed a major quality of the cult image. True to its nature, it remains "distant, however close it may be." [“WA," p. 243 n. 5]

The distance is equated, paradoxically, with presence through another definition, albeit a negative one: "Even the most perfect reproduction of a work of art is lacking in one element: its presence in time and space, its unique existence at the place where it happens to be.... One might subsume the eliminated element in the term 'aura' and go on to say: that which withers in the age of mechanical reproduction is the aura of the work of art" ("WA," pp. 220-21). Benjamin comments on the intrinsic violence of modern perception, arguing that "to pry an object from its shell, to destroy its aura, is the mark of a perception whose "sense of the universal equality of things' has increased to such a degree that it extracts it even from a unique object by means of reproduction" ("WA," p. 223)..$^{90}$

The aura of Buddhist icons has to do with the deposit of relics within them and their ritual consecration: the term aura means "breath," and the consecration is an "installation of the breaths" (prānapratisț $\bar{a})$. In some cases, this aura also has to do with the beliefs in the divine power of the material element, stone or wood, as in the ichiboku (one-piece)

90. Perhaps owing to Brechtian influence, Benjamin is nevertheless ambivalent about this evolution, which he also saw as a sign of democratization, of the legitimate ambition of the "masses" to overcome cultural privileges: "Every day the urge grows stronger to get hold of an object at very close range by way of its likeness, its reproduction" ("WA," p. 223). The desacralization of the work of art was also for him an emancipation from its "parasitic" existence as an element of ritual ("WA," p. 224). In an earlier essay on photography, Benjamin attributed the aura to the technical conditions of photography. The nihilism of "The Work of Art in the Age of Mechanical Reproduction" is also contradicted by his later essay, “On Some Motifs in Baudelaire." On this question, see Rainer Rochlitz, Le Désenchantement de l'art: La Philosophie de Walter Benjamin (Paris, 1992), pp. 174-94, trans. Jane Marie Todd, under the title The Disenchantment of Art: The Philosophy of Walter Benjamin (New York, 1996); and Mitchell, Iconology, pp. 178-85. For a positive conception of mimesis and reproduction, see also Michael Taussig, Mimesis and Alterity: A Particular History of the Senses (New York, 1993). 
sculpture in Japan: "The god in the unworked stone or stock continues to reside in the worked stone or stock." ${ }^{11}$ This is also true, for instance, of the "miraculous" logs, found in many legends. In other cases, the wood is empowered during consecration ceremonies that take place once carving is initiated ${ }^{92}$ Finally, the aura is often explained as resulting from an unbroken line of mimesis and contact between the first icon and its later reproductions-the power of this first icon, the Udayana image, itself owing to its resemblance to and contact with the Buddha himself. The importance of the initial view of the Buddha can also be explained in terms of verisimilitude. This is also true for the Chinese representations of the eighteen arhats, whose prototype was initially seen by the poetmonk Guanxiu in a dream. In all cases, the existence of a direct link, historical or metaphysical, with the ultramundane prototype is essential in order for it to become present in the icon-hence the critical role of textual iconographies as a source of models. Just as the vera eikon was imbued with the power of Christ through the impression of his face, the efficacy of Buddhist icons derives from their initial contact with the Buddha. This contact, however, does not have to be with the Buddha in the flesh, since his body was already, in a sense, merely an icon or a trace, an embodiment of the truth or dharma. Other traces or substitute bodies may have a similar effect. The Buddhist tradition seems to have hesitated between two models, one that insists on the superior value of the original or historical Buddha, and another that, in an almost Derridean fashion, undermines that foundation with its emphasis on the notion of traces. After the death of the Buddha, the sacred places where his paradigmatic life had unfolded and where his stupas remained came to play a similar role in the production of presence.

To what extent, then, does the reproduction affect the effectiveness of the image? Is not the materialization of a halo or aureole around the head or body of Buddhist statues already a sign of their loss of the true aura (in the Benjaminian sense)? More to the point, the Benjaminian notion of a loss of aura through photographic reproduction may have serious implications for the historian of Asian religions. As any fieldworker knows, there is a clear sense of profanation when taking photos in a cultic context; often the native objection against photos is that they will diminish the "efficacy" (ling), or what we may as well call the aura, of the icon. I recall a Japanese Buddhist monk who, when I asked him if I could take a picture of a particularly powerful icon, argued that the im-

91. See Christine Guth Kanda, Shinzō: Hachiman Imagery and Its Development (Cambridge, Mass., 1985), p. 73: "The sheer bulk and lack of mobility either in pose or in the articulation of bodily mass gives them a primeval aura" (my italics).

92. See Yiengpruksawan, "Gods in Pieces: The Ontological Ramifications of the Joined-Wood Technique in Japanese Buddhist Statuary" (forthcoming). 
age would not imprint on my film. We are clearly the descendants of our Orientalist fathers in this and other respects: although we no longer steal and behead statues (at least most of us), who does not have in his or her possession Buddhist icons (in one form or another) whose provenance will remain conveniently vague?

In modern society, Berger comments, "works of art are discussed and presented as though they were holy relics" (WS, p. 21). He disapproves of such fetishism. But one might want to see works of art truly treated as relics, precisely because relics were not the object of the kind of "bogus religiosity" that "has become the substitute for what paintings lost when the camera made them reproducible" (WS, pp. 21, 23). If this "bogus religiosity" is nostalgic, so is its critique. Berger, in fact, shows that photographic reproduction is responsible for a recrudescence of the nostalgia for the aura. What exactly distinguishes this "bogus religiosity" from Benjamin's authentic religiosity is not always clear, even if the new kind of impressive, mysterious aura no longer pervades the artwork "because of what it shows - . . because of the meaning of its image," but "because of its market value" (WS, p. 23).

The standardized production of icons in Japan after the eleventh century already resulted in a kind of commodity fetishism. As Christine Guth writes of the earlier period: "In preserving the cylindrical mass of the log from which an image is carved, Japanese sculpture of this period has an inner life and immediacy-qualities lost in later images of the joined-wood type." ${ }^{93}$ Clearly the shift from one-piece to prefab icons marks a watershed in icon production (and perhaps in icon reception). It does not mean that the cultic value has disappeared, although it might indeed have weakened, but the dissemination of power or sacrality (ling) is what justifies the multiplication of icons in the first place. Depending on circumstances, this dissemination can reflect (or produce) both an increase and a decrease in belief. The weakening of the icon's power, or rather the alternation between belief and disbelief that characterizes the icon as a dialectical image, is well illustrated by the story of the future shogun Yoritomo carrying a figurine of Kannon on his headdress, yet simultaneously not wanting it to be found by his enemies for fear of ridicule. In medieval Japanese Buddhism, as in the contemporary Thai case described by Stanley Tambiah, we find a massive production of amulets, but these amulets are charged by the monks, imbued with power. ${ }^{94}$ Similarly in seventeenth-century France, the dissemination of the king's portrait sometimes weakens but most often reinforces the belief that the portrait of the king is the king-a king who no longer has merely "two bodies," but a multitude. 


\section{Double, Double, Toil and Trouble}

In China, the first effigies, sometimes automata, are found in graves and seem to have been substitutes for real people, meant to accompany the deceased to the other world..$^{95}$ As Delahaye points out, "the doubles, $o u$, are beings, living or not, with whom one forms a couple. In numerology, ou refers to even numbers; it is opposed to $q i$, meaning odd number, but also unique, extraordinary, which has no match" (“AM," p. 52 n. 7). ${ }^{96}$

The icons are therefore quite literally "figures or images of the double" (in Chinese, ouxiang; in Japanese, guzo, meaning "statue" or "idol"). The original may be the god, or the worshipper. The correspondence between the icon and its human counterpart is such that the sympathetic magic works even on iconoclasts. We are told, for instance, of a despot who urinated on a statue that he had put in the privy and later suffered from a terrible pain in the scrotum that ceased only when he repented; ${ }^{97}$ and of the case of an iconoclastic Tang emperor, who, upon finding out that an icon of Guanyin had not been destroyed according to his orders, hit it in the chest and subsequently died of chest cancer. The notion of physical correspondence between the icon and its human counterpart is a basic feature of black magic. ${ }^{98}$ It also explains why people in Japan often stick an ex-voto or a golden leaf on the icon or caress its body at the point corresponding to the part of their body which hurts. An interesting case is that of the bodhisattva Kuginuki ("Nail-pulling") Jizō, whose emblem is a pair of pliers. In a small temple in Kyoto, dedicated to that particular Jizō, the presence at the gate of a giant pair of pliers, the size of a person and wearing a child's bib, shows the complex nature of some icons. One could, paraphrasing Magritte, say, "this is not a pair of pliers" (although clearly Magritte's point was different). It represents at the same time an obvious symbolism (the nail as physical pain, nail-pulling as removing the

95. See Li Chi: Book of Rites; An Encyclopedia of Ancient Ceremonial Usages, Religious Creeds, and Social Institutions, trans. James Legge, ed. Ch'u Chai and Winberg Chai, 2 vols. (Hyde Park, N.Y., 1967), 1:173. See also J. J. M. de Groot, The Religious System of China: Its Ancient Forms, Evolution, History and Present Aspect, Manners, Customs, and Social Institutions Connected Therewith, 6 vols. (1892; Taipei, 1982), 2:806-11.

96. The Dictionnaire français de la langue chinoise (Taipei, 1976), s.v. "ou," has: "statue (representing a person), doll, idol; even number; together; to pair, to mate; pair, couple, member of a couple, spouse, partner; to match, to go together, etc.; to coincide, hence coincidence: fortuitous, chance, accidental." $Q i$ also means "to exceed," "remainder," "bad luck," "bad omen."

97. See Donald E. Gjertson, "The Early Chinese Buddhist Miracle Tale: A Preliminary Survey," Journal of the American Oriental Society 101 (July-Sept. 1981): 297.

98. In his famous description of sympathetic magic, Frazer mentions the Chinese "effigies made of bamboo splinters and paper" known as "'substitutes of persons,"” which could be used to inflict harm on one's enemies (J. G. Frazer, The Magic Art and the Evolution of Kings, vol. 1 of The Golden Bough: A Study in Magic and Religion, 3d ed. [London, 1911], p. 60). See also Taussig, Mimesis and Alterity, pp. 44-58. 
pain) and a substitute body, not only of Jizō (as indicated by the bib, a traditional attribute of this protector of children), but also of the worshipper, who touches this paradoxical, nonanthropomorphic "Buddha to stroke" at various places before rubbing the corresponding painful parts of his or her own body.

The icons of the Buddha are sometimes compared to the "original" shadow that he is said to have left in a cave at Nāgarahāra, in Central Asia. This shadow, which became the source of another iconographic tradition, was described by the Chinese pilgrim Xuanzang (600-664), who was able to see it only after prostrating himself several hundred times. The shadow, invisible at first, eventually appeared in its full glory, with a cohort of bodhisattvas and celestial musicians, "as when the clouds open to reveal the golden Mountain." ${ }^{99}$ Likewise, the first Chan patriarch Bodhidharma left his shadow on a rock on Mount Song, near the cave where he had practiced his legendary "wall contemplation." As a focus of worship in the Chan/Zen tradition, this shadow plays a role equivalent to that of another famous relic, the flesh-body or mummy of the sixth patriarch Huineng.

The notion of the double leads us to examine the relation between the aura and the Freudian notion of the uncanny. Taking some of his cues from Hoffmann's story of the Sandman, Freud sees a paradigmatic example of uncanniness in the motif of the double, that is, in the relation between "persons who are considered identical by reason of looking alike." This relation, in Hoffmann, is accentuated "by transferring mental processes from the one person to the other-what we should call telepathy - so that the one possesses knowledge, feeling and experience in common with the other, identifies himself with another person, so that his self becomes confounded, or the foreign self is substituted for his ownin other words, by doubling, dividing and interchanging the self." 100 Freud considers that the double was originally a protection against the disappearance of the self, or, in Otto Rank's words, "an energetic denial of the power of death." He suggests that the "immortal" soul was the first double of the body (quoted in "U," p. 387). Originally a product of "primary narcissism," an assurance of immortality, the double tends to become, when the narcissistic phase is left behind, precisely the opposite: a ghastly harbinger of death ("U," p. 387). The conscience is another kind of double, a psychological double, but one that does not produce a feeling of the uncanny. Thus, for Freud, the double, as a figure of the uncanny, is the return of something once "familiar" but eventually repressed ("U,"

99. See Hwui Li, The Life of Hiuen-Tsiang, ed. Samuel Beal (London, 1914), p. 62. See also Malcolm David Eckel, "The Power of the Buddha's Absence: On the Foundations of Mahāyāna Buddhist Ritual," Journal of Ritual Studies 4, no. 2 (1990): 68.

100. Sigmund Freud, "The 'Uncanny," Collected Papers, trans. and ed. Joan Riviere, 4 vols. (New York, 1925), 4:386-87; hereafter abbreviated "U." 
p. 394). It is in particular the return, or apparent confirmation, of animistic beliefs that we thought we had surmounted (see "U," p. 402).

One of the best expressions of the uncanniness of the double is given by Oscar Wilde in The Picture of Dorian Gray. Here, a reversal takes place between the "real" (Dorian Gray) and his double (his portrait), his "truth in painting." The portrait undergoes all kinds of changes while Dorian remains eternally young, until he tries to get rid of his shadow, the silent witness to his depravation, without realizing that it is himself. By trying to destroy it, he ends up killing himself, effecting one last reversal. ${ }^{101}$ This illustration of the expression "le mort saisit le vif" recalls the traditional Chinese belief that the subject of a painting sometimes dies when the painting is finished: all his or her life flows into the double. It explains in part the custom of painting only the portraits of the dead.

The multiplication of icons in medieval Japan - which could be seen, with some qualifications, as their commodification-suggests the relevance of the problematic of fetishism and projection. A notion of projection that prefigures the Marxist concept can be found at the basis of the idealist tendency in Mahāyāna Buddhism (Yogācāra, Chan), but it was counterbalanced, in other parts of this tradition ("gradual" Chan, Pure Land, Vajrayāna), by a belief that subjects do not necessarily alienate themselves or become dependent on objects (icons) when they project themselves into them. The priest who projects his Buddhahood into a material support, a wooden icon, does not fall into the trap of fetishismlet alone of primary narcissism. He can eventually bridge the gap, the cleavage of the self, when he reintegrates in his self-consciousness the power temporarily projected into the icon. Here again we encounter the metaphor of the symbol, the split image, and the reunion of the tallies: divided in order to be reunited. Another paradigmatic expression of the folded structure of reality and its resolution is found in Hegel's statement, "As a spirit, man does not have an immediate existence but is essentially returned-home-to-self (in sich Zurückgekehrtes). This movement of mediation (Vermittelung) is an essential moment of the spirit. Its activity consists in transcending and negating its immediacy so as to return upon itself (Rückkehr in sich)." ${ }^{102}$

Whereas Freud saw in the objectivation of doubles a return of the repressed, Clément Rosset analyzes it in metaphysical terms as an instinctive denial of immediacy, the constant search for a deeper, hidden reality that replicates, subverts, or legitimizes that of the everyday world. Here the duplicated original is no longer an object or event of the outside world but the subject itself. ${ }^{103}$ It is the very self that loses some of its onto-

101. See Oscar Wilde, The Picture of Dorian Gray (New York, 1993).

102. Quoted in Derrida, Glas, trans. John P. Leavey, Jr. and Richard Rand (Lincoln, Nebr., 1986), p. 28.

103. See Clément Rosset, Le Réel et son double (Paris, 1976), p. 84. 
logical reality that becomes the double, the shadow of a greater reality. Speculations about the shadow, or the double, lead to a feeling well expressed by Rimbaud: "Je est un autre." ${ }^{104}$ Rosset denounces this feeling as an illusion that will ultimately receive a reality check with the advent of death. As in the case of the French and English kings, the Chan/Zen master's two bodies turn out to be a mere single body, and a very mortal one. ${ }^{105}$ "The different aspects of [this illusion]," writes Rosset, "refer to a same function, a same structure, a same failure. The function: to protect one from the real. The structure: not to refuse to perceive the real, but to double it. The failure: to recognize too late in the protecting double the very same real against which one believed to have guarded oneself." 106

The Buddhist theory of the Two Truths, or two levels of reality, introduces into the real a duplicity of which the iconic doubles are merely particular cases. In a poem on an icon, for instance, the Lu Shan master Huiyuan reflects on the Buddha's simultaneous existence on both levels: "In the tasteless void he has sketched his countenance. / Touching the surface of emptiness he transmitted his image." 107 The much-vaunted iconoclasm of Chan/Zen, based on the notion of immediacy, is belied by the adherence of this school to the Two Truths theory, which implies a bifurcation of the real, two levels of reality rather than a single, and therefore the use of symbols to mediate between them, to bridge the gap. This two-tiered structure should be seen as the symbolic structure, the structure of the symbol itself. Thus, the opposite (and counterpart) of immediacy is mediation, duplication, the double, the icon. The Chan/Zen rhetoric of immediacy is also a rhetoric of iconoclasm. ${ }^{108}$ Conversely, there is a rhetoric of mediacy - that of iconophilia.

Consider the Japanese contrast between the butsuzō (Buddhist icon) and the shinzo (icon of the kami, or god): whereas the latter were made of a single block, the former were, from the eleventh century onward, usually made of joined woodblocks. Like the shintai (divine body) - a sacred mirror in the case of the sun-goddess Amaterasu-the shinzo clearly func-

104. Arthur Rimbaud, "À Georges Izambard," in Rimbaud, Cros, Corbière, Lautréamont: Oeuvres poétiques complètes, ed. Alain Blottière et al. (Paris, 1980), p. 184.

105. See Alain Boureau, Le Simple Corps du roi: L'Impossible Sacralité des souverains français, XVe-XVIIIe siècle (Paris, 1988) - a critical complement to Ernest H. Kantorowicz's The King's Two Bodies: A Study in Mediaeval Political Theology (Princeton, N.J., 1957).

106. "Les différents aspects de l'illusion décrits ci-dessus renvoient à une même fonction, à une même structure, à une même échec. La fonction: protéger du réel. La structure: non pas refuser de percevoir le réel, mais le dédoubler. L'échec: reconnaître trop tard dans le double protecteur le réel même dont on croyait s'être gardé" (Rosset, Le Réel et son double, p. 123).

107. Quoted in Shaw, "Buddhist and Taoist Influences on Chinese Landscape Painting,” p. 199. See also Erik Zürcher, The Buddhist Conquest of China: The Spread and Adaptation of Buddhism in Early Medieval China, 2 vols. (Leiden, 1959), 1:242-3.

108. On the rhetoric of iconoclasm in Western discourse, see Mitchell, Iconology, pp. 160-208, and Goux, Symbolic Economies, pp. 134-50. 
tions as a double; there is only one in each shrine, and it is hidden. Guth contrasts this unicity with the multiplication in Buddhism of images that function primarily as aids to visualization. ${ }^{109}$ However, one should distinguish between those Buddhist icons that are multiplied and offered to the gaze of worshippers and those-like the master's portrait (chinzō), the mummy, or the "hidden Buddhas" (hibutsu) — that remain sequestered in the temple's inner sanctum. The former serve as aids to visualization (but also as ex-votos), whereas the latter remain the invisible bodies (or doubles) of the gods.

\section{The Buddhist Ideology of Aniconism}

Aniconism is not a lack of images, a default, but rather an excess, crossing through and beyond images. Recently, Susan Huntington has reopened the old "debate on Buddhist aniconism" by arguing that "representations of Buddhas were being produced at the same time as the socalled aniconic reliefs." 110 Huntington correctly points out the presuppositions regarding the superiority of iconism (and of Western/Greek art) of Alfred Foucher and others. However, her claim that the aniconic symbols are not surrogates for Buddha images or descriptions of events in the life of the Buddha but "portraits" of the sites of Buddhist devotion merely displaces the problem. As she herself points out, these sites were themselves surrogates for the Buddha, "traces" or "relics" ("EB," p. 406). Her belief in the "intrinsic meaning of the art" hardly represents progress, and Vidya Dehejia is right to emphasize in her response to Huntington the multivalence of emblems ("EB," p. 406). ${ }^{11}$ Regrettably, both Huntington and Dehejia seem to ignore the work of Mus, although he provided a much more comprehensive solution to their problem by placing Buddhist imagery in the context of Brahmanic aniconism. ${ }^{112}$

The traditional view that there were no images of the Buddha in early Buddhism led to the Orientalist belief that this religion was artistically, therefore spiritually, inferior. Yet, as Freedberg notes, aniconism (or nonfigurative art) is always on the side of "spirituality" (PI, p. 54). ${ }^{113}$ In

109. See Guth Kanda, Shinzō, pp. 18-22.

110. Susan L. Huntington, "Early Buddhist Art and the Theory of Aniconism," Art Journal 49 (Winter 1990): 402; hereafter abbreviated "EB.” See also Vidya Dehejia, "Aniconism and the Multivalence of Emblems," Ars Orientalis 21 (1990): 45-66. Dehejia argues that, while it is true that Foucher misstated the nature and extent of aniconism, he was accurate in perceiving its existence; see p. 64.

111. On Foucher, see also "IW."

112. See Mus, Barabudur, pp. 43-45, 60-66.

113. The best representative of this trend is probably Wassily Kandinsky, On the Spiritual in Art, in Kandinsky: Complete Writings on Art, trans. and ed. Kenneth C. Lindsay and Peter Vergo, 2 vols. (Boston, 1982), 1:114-219. 
the Indian context, however, Buddhist aniconism should have been read as a claim for spiritual superiority. In China as well, there is a strong connection between xenophobia and the Confucian criticism of the cult of images as a form of degeneration, as expressed by Confucians such as Yaochong or Han Yu. Similarly, Chan/Zen iconoclasm is often seen as the expression of a Buddhist theory of the sublime or the unrepresentable. Consequently, Chan/Zen paintings, with their rarefied atmosphere and their tendency toward abstraction, are perceived as a concrete illustration of the passage beyond the representation of objective reality, a freedom from what Kazimir Malevitch has called the useless weight of the object. However, the claim for aniconism or immediacy, wherever it is found, must be read as ideological. Aniconism is usually part of a general discursive strategy. For instance, with a similar aniconic gesture Plato denigrates materiality, mimesis, and the Cratylian conception of language, as well as the work of poets (ut pictura poesis). Standing at the other end of this philosophical tradition, Heidegger wants to present the work of art as a self-revelation of truth; however, in the process he reduces the image to the poem (ut poesis pictura).

With their rationalist bent, orthodox Buddhists probably had an axe to grind against Indian polytheism and its cult of images. However, archeological evidence seems to run contrary to their claims. Inasmuch as Buddhism is a product of Indian culture, there is reason to believe that the use of symbols in early Buddhism was never strictly the result of a purely aniconic teaching, a fortiori, of some figurative incapacity. Could we argue that the nonfigurative was perceived as ritually more efficient than the figurative? Freedberg would disagree. For him, there are only different kinds of likeness, some obvious to us, others not (see PI, p. 203). But this seems to beg the question.

According to Mus, however, the nonfigurative nature of the Vedic fire altar, with its schemas, diagrams, and symbols, is precisely what makes it more strongly expressive of man and, more specifically, of his immortality. The altar is an architectural double, a substitute body made the size (taille) of the sacrificer. It is an image, a "symbol" in the etymological sense, that is, a temporary double of the sacrificer, whose final image will be his funerary tumulus, itself measured in the same way. This nonfigurative yet ultrasymbolic monument is more sacred, more ritually efficacious, more "powerful," than any anthropomorphic figure. It is an eminent representation or "making-present," not an imperfect one. Anthropomorphic figures or figurations appear only downstream; they are logically (not chronologically) derivative. A nonfigurative representation like the abstract linga of Siva remains more potent than any ithyphallic image. We also find hybrid cases, in which nonanthropomorphic icons are worshipped in anthropomorphic fashion: for instance, posts or erected stones are clothed like the more anthropomorphic representations of the deity and/or dotted with eyes. In this context, Mus argues, 
the aniconism of ancient Buddhist art no longer seems problematic: it can be seen as a partial, reserved, or eminent aniconism. ${ }^{114}$ Similarly, in the Hindu temple, icons are projections of the central god, which is often a nonfigurative linga. The notions of aniconic center and iconic periphery explain the importance of the circumambulation (pradaksina $\overline{\text { ) }}$ that leads the practitioner from periphery to center, from bottom to top, from the senses to the spirit, from multiplicity to oneness.

From the question of aniconism, we move now, in circumambulatory fashion, to those of figuration, anthropomorphism, and realism, which are at the center of Freedberg's work on the "power of images." Verisimilitude is indeed important, not only in the case of the funerary portraits (chinzō), but for all Buddhist images modelled after the Udayana icon. Yet the conventional view is that Indian art is after the type, not the individual; and one may argue that the Sākyamuni of Seiryōji in Kyoto, supposedly a replica of the Udayana icon itself, is quite "typical." There is a tension between the symbol (for instance the ușnisa), which connotes divine transcendence, and a verisimilitude that denotes humanity-although the distinction is not always clear-cut (the usnisa may at times simply represent a concrete fleshy protuberance on the top of the head). If resemblance is the goal, how do we explain the coexistence of resembling and nonresembling icons? Freedberg claims that we may not see what other cultures see as resemblance. But, precisely, what is the line between what we see as resembling and what we do not see as such? If this line is not the same for all, how can one claim that we all look for the same verisimilitude? How do we avoid the teleological schema (denounced by Freedberg) and say that the verisimilitude aimed at by "primitives"-in their fetishes for instance-is not as verisimilar as ours? How do we include under that rubric objects that are clearly not very true to life, yet that are obviously quite powerful and animated? Why would a priest be glad to "dot the eyes" of a funerary tablet when he could instead dot the eyes of a wax effigy? Should we not keep an eye on that distinction? Can we simply reduce everything to figuration? A conception of verisimilitude that relies on figuration implies a notion of mimesis, which is understood quite differently in the Chinese or Japanese contexts. How does it play out in the case of Buddhist "realism" (for example, the Kamakura statuary)? Is the addition of real hair aimed at making the icon more "realistic" (that is, at verisimilitude) or more "real" (that is, at animation)? Why, if we admit Freedberg's point, would the eucharist have remained noniconic, yet so powerful? Why not some homunculus, a kind of gingerbread man, then? Surely not simply because the cannibalistic nature of the ritual would have become too obvious and unpalatable?

The resemblance between the icon and its worshipper is not so much a question of verisimilitude as one of size (as noted earlier, the Vedic altar 
and Buddhist icons are made according to the size of the worshipper) and of the presence of certain symbolic markers. Even when likeness is deemed essential, it is not sufficient. A case in point is that of a decorative painting by Huang Quan, a tenth-century Chinese painter who specialized in flower and bird paintings, on the walls of the palace of the King of Shu, that was so realistic that a falcon offered to the king mistook the painted pheasants in it for real ones. ${ }^{115}$ The text commemorating the incident states that "among the six principles" of higher art, only the "resemblance to form" and the "harmony of breath" are essential. If the "harmony of breath" is found without formal resemblance, substance dominates over ornament. To have only "formal resemblance," however, is like having the flower without the fruit. While likeness and spirit are harmoniously balanced here, in many other texts the emphasis is on the spirit. A case in point is that of Gu Kaizhi, who would paint a portrait and sometimes not dot the eyes for several years. When someone asked his reason for this, Gu replied, "'The beauty or ugliness of the four limbs basically bears no relation to the most subtle part of a painting. What conveys the spirit and portrays the likeness lies precisely in these dots."'116 In the case of sculptures, too, one can distinguish between animation in principle ("installation of breath") and in fact (for example, articulate limbs). In Western art as well, a prejudice against verisimilitude is evident, but it appeared quite late and did not constitute a dominant feature of the iconic tradition. This explains Freedberg's emphasis on the power of likeness, but it does not justify his attempt to generalize it to nonWestern cultures. Many of his conclusions derive from the fact that his narrative moves, as it were, teleologically, from the figurative to the nonfigurative icon (and not the other way around). Asian "realism" arises not only from increasing skill in naturalistic representation but from a conscious will to render the invisible visible, or the dead present. In Buddhist hagiography, the mummy of a dead master, when it happens to be discovered, always looks "as if alive"-precisely the same topos found in the case of a "realistic" icon.

Where Freedberg sees sexuality arousing the beholder because of the likeness of the image, Heidegger would see the unfolding (Ereignis) of Being: "This nature of truth which is familiar to us-correctness in representation-stands and falls with truth as unconcealedness of beings" ("OW," p. 52). What Freedberg considers to be the ne plus ultra of verisimilitude, the real costume of certain icons, can play quite a different role in the Buddhist context. There are some well-known cases in Japanese Buddhism of icons whose body is represented with "soft" realism (for

115. This calls to mind the painting of a nineteenth-century experiment, whose reference escapes me, in which real cows are put in front of painted cows to test the mimetic quality of the painting in the painting.

116. Liu Yiqing, Shishuo xinyu jiaojian (Collected Notes on "A New Account of Tales of the World"). 
instance, the so-called naked Jizō or Benzaiten). These icons were originally clothed like noble human beings. The same is true of the mummies of Buddhist priests. However, one may wonder what role this parure (Kant's parergon) plays in the general economy of Buddhist ritual. In a seminal essay entitled "Le Buddha paré" (The Adorned Buddha) Mus has shown in the case of Săkyamuni that the nature of an icon can change along with its parure, its finery: instead of descending further into the world of appearances, as we might assume at first glance, it now transcends it; it no longer manifests its (relative) "metamorphic body" (nirmānakāya), but its (absolute) "dharma body" (dharmakāya). ${ }^{117}$ But things are not always so paradoxically simple, and one may argue that, in most cases, the uncarved woodblock (or at least the single woodblock icon) is closer to the transcendental Buddha. We seem to have here two different ways of conceiving the excess of representation (the sublime): as an additional layer of symbolism (cloth, parergon), or as a total stripping (like the nudity of the "heavenly-clad" ascetic in Jainism).

\section{And So?}

It is clearly impossible to return to a premodern conception of the icon, or to retrieve non-Western conceptions of it, to abandon the vantage point (or disadvantage point) of our self-centered perspective. I suggested above that an intrinsic quality of the modern (and, by the way, predominantly male) gaze is the violence it does to images. Perhaps one cannot avoid the most subtle forms of that violence. At any rate, there is little to be gained by adopting a nostalgic approach that idealizes the past (an idealization that is just the other side of the coin, as the case of Segalen shows) and clings to tradition.

Our use (or abuse) of these icons may be not only the unavoidable outcome of modern commodity fetishism but also part of a Western pragmatic which consists in installing cultural fragments in another context (Malraux's musée imaginaire), reinscribing them in another structure, and thus establishing another circulation of power. These icons remind me of Nancy Jay's example of the churinga (an Australian Aboriginal ritual instrument, a sort of bull-roarer) in a museum, which she compared to Confederate money, about which one thing is certain: it is no longer money, although we do not know what kind of object it is. ${ }^{118}$ One could also argue that, despite the apparent novelty, there is nothing radically new here: the icon was always already reinscribed or disseminated. If we

117. Mus, "Le Buddha paré. Son Origine indienne. Çākyamuni dans le mahāyānisme moyen," pt. 2 of "Études indiennes et indochinoises," Bulletin de l'École Française d'ExtrêmeOrient 28 nos. 1-2 (1928): 197.

118. See Nancy Jay, Throughout Your Generations Forever: Sacrifice, Religion, and Paternity (Chicago, 1992), p. 12. 
still believe that this disenchantment is radical and irreversible, should we then mourn it? Benjamin was the first to theorize this disenchantment of the work of art in the age of mechanical reproduction. The example he focusses on, the photograph, is interesting since, as he rightly points out, it retains some of the individual aura (and we know that photos can be used as substitute bodies in black magic). But above all, if some photos do lose their aura through reproduction, others regain another type of aura, or, rather, present an aura that was not apparent in the original subject. Clearly, the reproduction of votive images does not result in the loss of their aura; Benjamin's earlier insight that the aura was in part the product of the photographical technique would seem more to the point here. ${ }^{119}$ At any rate, the notion of aura might be useful even in the case of noncultic images. One could also argue that the multiplication of images, rather than depleting their aura, renders presence "immediate and indubitable" (PI, p. 177). This is true with the portrait of the ruler, in the absolute monarchy that emerged in seventeenth-century France, as well as today in all regimes based on a cult of personality. Although Benjamin at one point considered the loss of the aura as a necessary counterpart to the democratization of art, in his argument about the unity of the work of art in its aura we can also perhaps hear a distant echo of the discourse of censorship, according to which prints, like photographs, are vulgar "because they can get into the hands of the vulgus, the crowd," and "are therefore not like art" (PI, p. 361).

There is therefore no need to wax nostalgic or nihilistic about the loss of the aura in the age of mechanical reproduction or the inauthenticity of the technical epoch. As Jean-François Lyotard remarks, Being "didn't choose Cézanne to express itself." 120 After all, the grandiloquent disclosure of truth that Heidegger attributed to the work of art can occur in the photos of, say, Man Ray or Henri Cartier-Bresson - and, with some luck, in my own amateurish photos as well. Similarly, the erotic aura is not limited to the "artistic" photos of Mapplethorpe. One could argue, as Freedberg does, that any erotic or pornographic picture has the potential to arouse a strong response from the beholder, to turn him into a voyeur. How this differs, then, from the voyeurism implicit in paintings like Giorgione's Tempesta- a voyeurism that is the main source of the fascination exerted by "classic" paintings such as this one-is not always clear. We may recall that fascination is derived from fascinus, the Latin word for phallus. Thus, my position here is by no means a nostalgic one. However, I want to emphasize again that the aura-which is perhaps not irreversibly lost, but often ignored or eclipsed-is an important aspect of these artworks and that one way to retrieve it-as it were, dialectically, through a kind of Buddhist "skillful means" (upayya) that could later be conve-

119. See Rochlitz, Le Désenchantement de l'art, p. 181.

120. Lyotard, "Philosophy and Painting in the Age of Their Experimentation," p. 189. 
niently abandoned-is to place it, as Benjamin argued, in its cultic context. This anthropological reinscription will help us to move beyond the cultural level to the phenomenological level.

Passing through customary readings of the icon (the aesthetic, symbolic, economic, anthropological), we have shifted from its readable/visible (or obvious) to its visual (or obtuse) dimension. The icon overflows from the aesthetic and symbolic spheres into the anthropological. The focus on the anthropological dimension referred to the belief in a presence, a transcendent immanence of the icon. However, one must be able to go beyond that dimension toward the phenomenological dimension, where the experience of the aura, now desacralized, secularized, reveals a more originary aspect of sense perception. ${ }^{121}$ Thus, going through the anthropological moment (by placing the icon in its cultural/cultic context), one ends up discovering a broader anthropological (in the philosophical sense) dimension of the aura, for which the cultic aspect is no longer essential, or, rather, from which it merely derives.

The Buddhist icon, like any true icon, is a métèque ("wog"), as Segalen would have described it, but for reasons that have less to do with designating cultural or artistic superiority or inferiority and more to do with the etymological root of the word (meta-oikos, literally, "one who moves to a different house"). This derivation is apt not only because the icon tends to move from temple to museum (or the antiquarian's shop) but because it is both within and above the oikos, the economy (oikonomia, the law of the house and of partition, distribution, and exchange): it simultaneously institutes the economic/iconomic circle and goes beyond it. ${ }^{122}$ In this hybrid and highly unstable figure, all human métèques and métis (half-breed, half-cast, or half-caste-a related word, although of different etymology) will recognize their prototype.

121. See Didi-Huberman, Ce que nous voyons, ce qui nous regarde, p. 125.

122. See Derrida, Given Time: I. Counterfeit Money, trans. Peggy Kamuf (Chicago, 1992), pp. 6-7, and Faure, Visions of Power, pp. 282-85. 